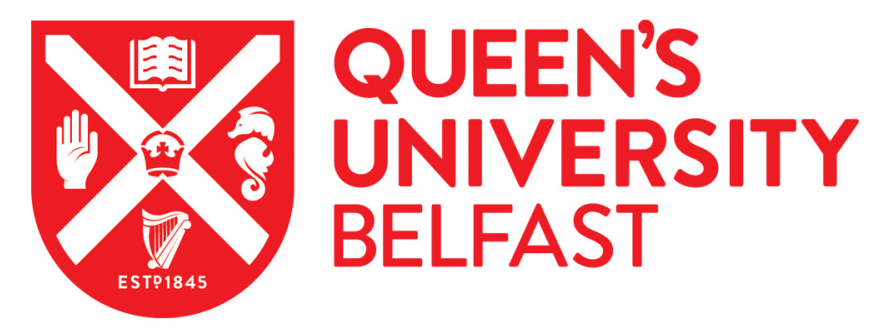

\title{
Homologous recombination deficiency in breast cancer: Implications for risk, cancer development, and therapy
}

Ali, R. M. M., Mclntosh, S. A., \& Savage, K. I. (2021). Homologous recombination deficiency in breast cancer: Implications for risk, cancer development, and therapy. Genes Chromosomes and Cancer, 60(5), 358-372. https://doi.org/10.1002/gcc.22921

Published in:

Genes Chromosomes and Cancer

Document Version:

Peer reviewed version

Queen's University Belfast - Research Portal:

Link to publication record in Queen's University Belfast Research Portal

Publisher rights

Copyright 2020 John Wiley and Sons

This work is made available online in accordance with the publisher's policies. Please refer to any applicable terms of use of the publisher.

\section{General rights}

Copyright for the publications made accessible via the Queen's University Belfast Research Portal is retained by the author(s) and / or other copyright owners and it is a condition of accessing these publications that users recognise and abide by the legal requirements associated with these rights.

Take down policy

The Research Portal is Queen's institutional repository that provides access to Queen's research output. Every effort has been made to ensure that content in the Research Portal does not infringe any person's rights, or applicable UK laws. If you discover content in the Research Portal that you believe breaches copyright or violates any law, please contact openaccess@qub.ac.uk. 
Homologous Recombination Deficiency in Breast Cancer: implications for risk, cancer

development and therapy

Abbreviated title: HRD in breast cancer

Rayhaan M.M. Ali, Stuart A. McIntosh", Kienan I. Savage*

Patrick G Johnston Centre for Cancer Research, Queen's University Belfast, 97 Lisburn Road, Belfast, United Kingdom, BT9 7AE.

Key words : breast cancer, homologous recombination, DNA repair, chemotherapy, PARP inhibitors

* Contributed equally, joint corresponding authors :

s.mcintosh@qub.ac.uk

k.savage@qub.ac.uk

\section{Abstract}

An underlying cause of breast cancers has been largely attributed to defects in the DNA damage response (DDR) pathway. In particular, the homologous recombination (HR) pathway repairs double-stranded breaks (DSBs) in DNA, ultimately protecting the cell from genomic instability and thus preventing the accumulation of transforming mutations. In line with this, mutations in a number of genes encoding HR proteins are a well-studied cause of HR deficiency (HRD), and, at the germline level, can confer risk to breast cancer but also

This article has been accepted for publication and undergone full peer review but has not been through the copyediting, typesetting, pagination and proofreading process which may lead to differences between this version and the Version of Record. Please ite this article as doi: $10.1002 /$ gcc.22921 
occur somatically, contributing to sporadic breast cancer development, progression and response to therapy. Our understanding of the biological processes involved in HR and how these become compromised during breast cancer development has led to a better understanding of how HRD cells can be targeted with specific DNA damaging agents and/or with synthetic lethal targeting approaches such as PARP inhibition. Additionally, in vitro and preclinical modelling has supported the development of clinical trials to assess targeted therapies such as PARP inhibitors (PARPis), ultimately leading to development of therapies with greater clinical benefit. A number of challenges have been encountered, including resistance to therapy; however, addressing these challenges head-on and continually driving scientific research and clinical trials with innovative therapies will contribute to our ability to target HRD in breast cancers. Ongoing research efforts into HRD in breast cancer development are therefore essential, even in the era of targeted therapies, to provide innovative strategies for improved tumour responses. 


\section{Introduction}

The cellular genome is continually exposed to DNA damaging events, including endogenous sources such as oxidation, alkylation and DNA base mismatches, as well as exogenous sources including ultraviolet (UV) radiation, ionizing radiation (IR) and other chemical agents including chemotherapeutics. Indeed, organisms have developed an armoury of defence pathways to overcome these DNA insults. This includes sensor proteins that detect DNA damage, transducers that mediate and/or amplify this information/signal and effectors, which regulate numerous cellular processes such as DNA damage checkpoint control, transcriptional reprogramming, RNA processing, DNA repair and apoptosis. Ultimately, this orchestrated process plays an essential role in detecting DNA lesions, signalling their presence and promoting their repair via DNA damage response (DDR) pathways, facilitating DNA repair and the maintenance of genomic integrity.

The major DNA repair pathways within human cells include direct damage reversal, base excision repair (BER), nucleotide excision repair (NER), DNA mismatch repair (MMR), inter-strand crosslink repair (Fanconi anaemia (FA)/BRCA), and the double strand break repair pathways homologous recombination (HR) and non-homologous end joining (NHEJ) ${ }^{1}$. DNA double-stranded breaks (DSBs) are considered the most severe DNA lesions, as these can result in loss and/or amplification of genetic information which, with the exception of some well characterised gain-of-function point mutations, are the main drivers of cancer, particularly breast cancer. HR encompasses a number of interrelated pathways that utilise the homologous sister chromatid for template-directed error-free DNA repair of DSBs, whilst NHEJ involves repair of DSBs via re-ligation of the DNA ends (potentially resulting in repair errors $)^{2}$.

A defect in any of these pathways can lead to genomic instability and mutagenesis, whereby the cell is unable to repair damaged DNA effectively. As genomic instability is a hallmark of 
cancer $^{3,4}$, it is unsurprising that the development of cancer is a consequence of DDR pathway defects, including HRD. Indeed, it has been estimated that up to $40 \%$ of familial and sporadic breast cancers have an HRD ${ }^{5}$, and understanding the link between HRD and breast cancer development at the molecular level has been crucial in developing targeted therapies for breast cancer treatment and understanding tumour response. Here, the role of HRD in breast cancer risk, development and treatment response is reviewed. 


\section{Homologous Recombination DNA Repair Pathway}

As highlighted above, HR is a relatively error-free DNA repair pathway, utilising a sister chromatid as a template for copying and replacing damaged DNA. Consequently, repair of DSBs via HR can only occur in the $\mathrm{S}$ and $\mathrm{G} 2$ phases of the cell cycle, during which a homologous sister chromatid is available.

Specifically, at the outset of HR, DSBs are sensed by a trimeric complex known as the MRN complex. This complex is composed of meiotic recombination 11 (MRE11), the DNA repair protein RAD50 and Nijmegen breakage syndrome 1 (NBS1) $)^{6}$. This initial sensing of DSBs is performed in combination with the human single strand binding protein (hSSB1) (the 'sensor' proteins) which directly binds to ends of DSBs tethering the MRN complex to broken DNA ends. MRN then recruits and activates the checkpoint kinase ATM (Ataxia Telangiectasia Mutated), which in turn phosphorylates a number of substrates involved in the signalling of DNA damage ('mediators'), at specific residues ${ }^{7}$. For example, at, and surrounding, the DSB site, ATM phosphorylates the histone protein $\mathrm{H} 2 \mathrm{AX}$ within the chromatin at serine 139 (Ser139) forming $\gamma \mathrm{H} 2 \mathrm{AX}$. The mediator of damage checkpoints protein 1 (MDC1) binds directly to $\gamma \mathrm{H} 2 \mathrm{AX}$ through its phosphoprotein interacting BRCT domain and recruits and helps activate additional ATM at the break site, thus amplifying and propagating the DDR signal $^{2}$. Additionally, Chk1 and Chk2 ('transducers'), which are directly phosphorylated and activated by ATM and the ATM and Rad3 related kinase ATR, are also involved in the signalling of DSBs and directly initiate cell cycle arrest to allow time for repair ${ }^{8-11}$. Structural changes in the chromatin surrounding DSBs also result in the binding of the pro-NHEJ factor 53BP1 to methylated histones surrounding the DSB site. Finally, the breast and ovarian cancer susceptibility protein BRCA1 associates with C-terminal binding protein interacting protein (CtIP), which then further interacts with the MRN complex ${ }^{12}$. Once the necessary proteins have been recruited to the DSB site, DNA end resection begins. This is performed 
by the MRN complex, and more specifically, by the Mre11 nuclease. Mre11 dependent DNA end resection requires $\mathrm{CtIP}$ and is catalysed by BRCA1, which promotes the removal/remodelling of 53BP1, a resection blocking protein, away from the DSB ends, thus facilitating HR mediated DSB repair. The combined efforts of MRN, CtIP and BRCA1 result in resection of the 5' DNA strand, resulting in a protracted 3' single stranded DNA (ssDNA) overhang. This 3' ssDNA, is rapidly bound/coated with replication protein A (RPA) to form a nucleoprotein filament, thus protecting it from degradation. Then, RPA is displaced through the recruitment of partner and localiser of BRCA2 (PALB2) which in turn recruits BRCA2, which then loads the recombinase RAD51 to replace RPA in a reaction promoted by mediator proteins, such as XRCC2, XRCC3 and RAD52 amongst others. This generates the Rad51-ssDNA-nucleoprotein filament that invades the homologous site within the doublestranded sister chromatid ${ }^{13}$. At this site, a transient displacement loop (D-loop) is formed which functions as a transient replication fork, allowing the replication machinery to replace damaged/resected DNA in an error free manner, after which the resultant Holliday junction is resolved, and the error-free repair of DNA is complete. This process is summarised briefly in

\section{Figure 1.}




\section{HR Defects and Breast Cancer}

It is evident that a number of proteins play a key role in the repair of DSBs by HR. Indeed, the importance of the breast and ovarian cancer susceptibility proteins BRCA1 and BRCA2 has been well documented, with the first suggestion of a role for BRCA1 in HR, due to its colocalisation with Rad51 following DNA damage, reported in 1997 by Scully et al ${ }^{14,15}$. In line with this, Moynahan and colleagues demonstrated that BRCA1 $1^{-/-}$mouse embryonic stem cells had a 5- to 6-fold lower level of HR activity than $\mathrm{BRCA}^{+/-}$cells ${ }^{16}$. A role for BRCA2 in HR was reported soon after, as BRCA2 contains a DNA binding domain (DBD) capable of interacting with dsDNA as well as RAD51, with early phenotypic studies showing BRCA2 depletion can lead to heightened sensitivity to DNA damaging agents and impaired HR following DNA damage ${ }^{17-21}$. Indeed, it is essential that the genes encoding these proteins function appropriately. For example, any mutations within these genes or genomic regulatory regions e.g. promoters/enhancers, may prevent optimal expression of these genes or the function of their encoded protein, thus affecting synthesis of functional HR proteins, leading to HRD and abnormal DSB repair. As a result of this deficient/abnormal DSB repair, HRD results in the accumulation of mutations/aberrations, ultimately leading to heritable genomic "scars" within HRD cells/tumours.

A number of factors can result in HRD (Figure 2). For example, epigenetic modification of the HR genes, such as inactivation of $B R C A 1$ or $R A D 51 C$ by promoter hypermethylation leading to downregulation of gene mRNA expression, has been shown to correlate with $\mathrm{HRD}^{22,23}$. A number of structural rearrangements may also lead to HRD. Telomeric allelic imbalance (TAI) is the unequal contribution of maternal and paternal DNA, whereby breakpoints in TAI regions can lead to imbalances and $\mathrm{HRD}^{24}$. This is part of the characteristic 'genomic scar' caused by HRD, which also includes loss of heterozygosity $(\mathrm{LOH})^{25}$ and large-scale state transitions $(\mathrm{LST})^{26} . \mathrm{LOH}$ is a frequent genetic event in many 
cancer types, during which a change in polymorphic markers from a heterozygous state in the germline to a homozygous state in the tumour DNA occurs ${ }^{27}$. LOH can involve copy number loss, whereby all or part of a chromosome has been deleted and has been identified on a number of chromosomal arms in breast cancer $^{28}$.

However, the most commonly described cause of HRD in the literature are deleterious mutations within the coding regions of genes encoding the core HR proteins (Figure 2) and such mutations may be either germline or somatic. Germline mutations in BRCA1 and $B R C A 2$ are the most well characterised cause of HRD, and the most common cause of hereditary breast and ovarian cancer $(\mathrm{HBOC})^{29}$. Although $B R C A 1 / 2$ variants confer a high risk of developing breast cancer (with a relative risk of 5 or higher), it has been estimated that only $4.6 \%$ of women have mutations in these genes, demonstrating that mutations in these genes are relatively rare in the general population ${ }^{30-32}$. Nonetheless, because the risk of breast cancer conferred by a germline $B R C A 1 / 2$ mutation is so high, $B R C A 1 / 2$ are classified as highpenetrance breast cancer genes (Table 1) ${ }^{33-35}$. Such BRCA mutations can downregulate HR, consequently favouring more error-prone DSB repair pathways (such as NHEJ). This may result in the introduction of mutations or large deletions in the DNA (the latter of which may include LOH), ultimately increasing the acquisition of tumorigenic structural rearrangements and genomic instability, leading to breast cancer (Figure 2).

It is important to note that the $B R C A$ genes do not explain the full extent of clinically relevant HRD in breast cancer. Indeed, breast tumours lacking $B R C A$ mutations but with HRD have been described, and implicated genes include those encoding proteins involved in DSB repair, which interact with BRCA1/2 during the HR process. HR genes with an established role in significantly increasing breast cancer risk include PALB2, ATM and CHEK2 (Table 1), which are part of a group of genes that increase breast cancer risk by approximately 2- to 5 -fold ${ }^{32}$, and are consequently classified as moderate-penetrance (or moderate-risk) genes. 
However, Antoniou et al suggested that variants in $P A L B 2$ confer a five-fold or higher risk of breast cancer $^{42}$, and both Slavin et al and Thompson et al classified PALB2 as a high risk gene for hereditary breast cancer ${ }^{32,50}$. Subsequently, it is now accepted that PALB2 is a high, rather than moderate risk, breast cancer gene.

Additional genes in the HR pathway, such as MRE11, RAD50 and NBS1 of the MRN complex and $R A D 51$ have been investigated for breast cancer risk, ${ }^{51}$ with a number of genes encoding the RAD51 paralogues, such as $R A D 51 B$ and $R A D 51 C$ being implicated. However, the level of risk associated with mutations in these genes is not clear, with conflicting findings reported. De Leeneer et al and Le Calvez-Kelm et al found that deleterious variants in $R A D 51 C$ do not increase breast cancer risk $^{52,53}$. Yet, a study by Jønson et al describes pathogenic $R A D 51 C$ variants and several variants of the gene, arguing that these should merit consideration of $R A D 51 C$ as contributing to breast cancer risk ${ }^{54}$. This and other studies investigating the variants in $R A D 51$ and their association with breast cancer risk ${ }^{32,55-58}$ illustrate the need to continue investigations in some of the HR moderate risk genes to further understand their contributions to breast cancer risk.

Mutations in these HR genes often result in decreased gene expression and consequently alter protein levels and function. This may lead to decreased HR and a shift towards more errorprone methods of DSB repair, or to increased expression of HR genes. This latter situation may also prove advantageous to the balance of the HR pathway. For example, past studies have overexpressed RAD51 paralogues (yeast and human, including RAD51D) in the context of mutants deficient in these paralogs. These studies illustrated that overexpressing RAD51D was able to rescue the HRD in the mutants such that they were resistant to DNA damage ${ }^{59-62}$. On the other hand, elevated RAD51 levels have been observed in breast cancer cell lines and primary tumours ${ }^{63,64}$ suggesting that driving the HR pathway above physiological levels may also play a role in genomic instability and hence tumour progression ${ }^{65}$. 
Additionally, certain HR genes have been associated with development of particular breast cancer subtypes. Clinically relevant breast cancer subtypes are detailed in Table 2. It is well-known that triple-negativity correlates with $B R C A 1$ status $^{70}$. In a recent case-control study by $\mathrm{Hu}$ et al, BRCA1, BRCA2 and PALB2 mutations were particularly associated with ER- and HER2- subtypes of breast cancer ${ }^{71}$ - also described in Table 2. TP53 (which encodes a tumour suppressor, controls cell cycle and activates DNA repair proteins such as RAD51) mutations, were shown to be enriched in the HER2+ subtypes - a finding also corroborated by Slavin et al in $2017^{32,36,37,72}$. ATM and CHEK2 mutations were associated with all subtypes except for triple negative breast cancers (TNBCs) with RAD51C and RAD51D mutations enriched in ER- tumours only. In 2018, Shimelis et al performed a 38 gene hereditary cancer panel test in 10,901 TNBC patients and revealed that germline pathogenic variants in the HR genes, including $B R C A 1$ and $R A D 51 D$, were associated with a high risk of TNBC. Pathogenic variants in BRIP1, RAD51C and TP53 were associated with moderate risk of $\mathrm{TNBC}^{73}$. Studies like these can help clinicians guide subtype-specific breast cancer risk and improve patient management e.g. through the use of anti-oestrogen medication for chemoprevention in women at high risk of developing ER positive disease. 


\section{HR Defects and Cancer Treatment}

For decades, anthracyclines (broad-spectrum anticancer drugs, which act by the inhibition of topoisomerase II) such as doxorubicin and epirubicin have been amongst the most widely used chemotherapeutic agents for breast cancer treatment. Anthracycline-containing chemotherapy regimens (so-called second generation regimens) have demonstrated survival benefits over combinations such as cyclophosphamide, methotrexate, and fluorouracil $(\mathrm{CMF})^{74-78}$. Furthermore, the use of taxanes (which act by binding to and stabilising microtubules to induce mitotic cell death), such as docetaxol and paclitaxel, in third generation treatment regimens, have been shown to be superior to anthracycline-containing second generation regimens alone in terms of overall survival ${ }^{79-81}$. However, there are currently no good biomarkers available to predict response to particular chemotherapeutic agents and thus generally anthracycline-taxane regimens are used irrespective of molecular subtype.

A key question for clinicians is whether an understanding of the genetic aberrations in hereditary breast cancer can be exploited to improve patient outcomes. The genomic instability induced by mutations in HR genes potentially renders cancer cells susceptible to chemotherapeutic drugs, particularly those which act directly to damage DNA, such as anthracyclines or platinums ${ }^{82-88}$. In support of this, a number pre-clinical studies have shown that BRCA1/2 deficient breast cancer cell lines, which lack functional HR, are much more sensitive to platinum-based drugs which induce inter-strand crosslinks ${ }^{89-98}$. For example, Bhattacharyya et al showed that $\mathrm{BRCA}^{-/-}$mouse embryonic stem cells were 5 -fold more sensitive to cisplatin when compared with wild-type cells ${ }^{90}$. Confirming this, Fedier et al demonstrated that human breast cancer cells deficient in BRCA1 had an increased sensitivity to the platinums carboplatin and oxaliplatin ${ }^{93}$. Cells from mice harbouring a deletion in exon 27 of $B R C A 2$ (the region to which RAD51 binds) were hypersensitive to mitomycin $\mathrm{C}$ (that 
induces DNA inter-strand crosslinks), an expected observation considering the role BRCA2 plays in $\mathrm{HR}^{95}$. Indeed, as this exon in $B R C A 2$ has been shown to maintain chromosomal integrity at stalled and collapsed replication forks during $\mathrm{HR}^{96}$, cells lacking this exon would be expected to have an increased sensitivity to platinum-based drugs. Indeed, Yuan et al show that ectopic expression of a truncated BRCA2 protein (containing part of the Rad51 binding domain) increases sensitivity to cisplatin in vivo, presumably via a dominant negative interaction ${ }^{98}$.

The clinical relevance of using platinum-based regimens in patients with a germline HRD has been explored in several clinical studies. Byrski et al in 2009 reported a small series of patients with pathogenic $B R C A 1$ mutations who received neoadjuvant treatment for breast cancer with cisplatin, reporting a pathological complete response (pCR) in $90 \%$ of patients ${ }^{84}$. A further retrospective study from this research group reported similarly high pCR rates in BRCA1 mutation carriers receiving neoadjuvant cisplatin $(83 \%)^{86}$. This finding was confirmed in a further study by Byrski et al in 2014, during which a pCR was observed in $61 \%$ of $B R C A 1$ mutant patients receiving neoadjuvant cisplatin ${ }^{99}$.

Several prospective clinical trials have been conducted to evaluate the role of platinums in the treatment of breast cancer. These studies have often included unselected TNBC patients, although many have also stratified patients by germline $B R C A$ mutation status. These studies are summarised in Table 3.

The TNBC Trial (TNT) phase III clinical trial compared carboplatin and docetaxol in unselected advanced TNBC. Overall, there was no difference in response rates (ORR) or progression-free survival (PFS) between the two groups. However, patients with a germline BRCA1/2 mutation treated with carboplatin had both improved PFS (6.8 vs 4.4 months, $\mathrm{p}=0.002)$ and ORR $(68 \%$ vs $33 \%, \mathrm{p}=0.03)$ when compared to those treated with docetaxol ${ }^{103}$. 
In this study, the authors used an HRD assay (also referred to as the Myriad HRD assay, developed by researchers of Myriad Genetics Inc., that tests for the presence of structural rearrangements across the genome and outputs an HRD score to tumours ${ }^{105}$ ) to identify patients with TNBC who potentially had genomic scarring arising as a consequence of an HRD, although patients with a high Myriad HRD score using this assay (unlike germline $B R C A 1 / 2$ mutation carriers) did not have a preferentially improved response to platinum ${ }^{103}$.

In contrast, several studies have investigated the benefit of platinums to chemotherapy regimens in early breast cancer with a putative HRD. The PrECOG 0105/Cisplatin-1 and Cisplatin-2, and GeparSixto trials suggested a benefit for the addition of platinums in the neoadjuvant setting, in patients with HRD+ tumours, whether classified by the presence of a germline BRCA1/2 mutation, or by the use of the Myriad HRD assay ${ }^{100,101}$. However, the TBCRC030 phase II study was a phase II randomised comparison of neoadjuvant cisplatin or paclitaxel in patients with TNBC of either BRCA wild type or unknown mutational status, using a cut-off of Myriad HRD score $\geq 33$. HRD was not found to be predictive of pathological response to chemotherapy, and there was no difference is response rates between platinum or taxane ${ }^{102}$.

SWOG S9313 identified improved outcomes in patients with an HRD (either germline $B R C A$ mutant or Myriad HRD $\geq 42$ ), who were treated with adjuvant anthracycline/cyclophosphamide, when compared to patients without an $\mathrm{HRD}^{104}$.

Overall, and notwithstanding some of the conflicting results from these clinical studies, there is a growing body of evidence that tumours with an HRD do derive a benefit from chemotherapeutic agents such as anthracyclines or platinums. The effectiveness of these agents is reflected in the role of BRCA1/2 in DNA repair pathways, whereby germline mutations in either gene impair HR repair of DSBs and cause an HRD leading to genomic 
instability. HR also contributes to repair DNA lesions (such as intra-strand crosslinks) induced by platinum-based cross-linking agents. Therefore, in the absence of functional BRCA proteins, cells are unable to repair these DNA breaks leading to apoptotic cell death of HR-defective cells (with a more limited effect on HR-proficient cells).

Whilst platinum agents may be relatively effective in treating $B R C A$-associated breast cancer, there may be significant associated toxicities. A recent meta-analysis of TNBC suggested that side-effects such as anaemia, thrombocytopaenia and nausea occurred more frequently in patients treated with platinum agents, who were also more likely to need dose reduction/or dose stopping due to toxicities ${ }^{106}$.

Thus, targeted synthetic lethal approaches, such as those utilising poly(ADP-ribose) polymerase (PARP) inhibitors (PARPis) in BRCA deficient cells have shown great promise in the clinic for patients with a $B R C A 1 / 2$ breast cancer ${ }^{107-109}$. PARP is an enzyme with a role in catalysing transfer of ADP-ribose to target proteins (including itself and many histone proteins), at SSBs within DNA. When PARP is inhibited, SSBs are not repaired, resulting in stalled replication forks during S-phase. The HR proteins, including BRCA1/2, are required to rescue these stalled forks. In the context of PARP inhibition and in the absence of BRCA1/2, DNA DSBs begin to accumulate during the S-phase (due to collapse of stalled replication forks). Consequently, this leads to apoptotic cell death of the HR-defective cells (with no effect on the HR-proficient cells). This concept is known as synthetic lethality (Figure 3). Indeed, PARPis are well tolerated because normal cells with at least one functional allele of $B R C A 1 / 2$ can overcome the effects of PARP inhibition, as they are able to rescue PARPi induced replication stress.

It was therefore hypothesised that PARPis will show clinical benefit in patients carrying a germline $B R C A$ mutation, as such mutations may potentially predict response to PARPis 
allowing clinicians to offer targeted therapy to germline $B R C A 1 / 2$ mutation carriers with breast cancer ${ }^{110}$. Consequently, PARPis have been the subject of investigation in several clinical trials assessing their benefit in $B R C A$-mutated breast cancer. Several studies in advanced breast cancer, including ICEBERG1, OlympiAD, EMBRACA and BROCADE3 have demonstrated benefit for PARP inhibition in advanced $B R C A$-mutated $\mathrm{TNBC}^{111-114}$, and these studies are summarised in Table 4. On the basis of these results, the FDA approved the use of olaparib to treat patients with HER2 negative breast cancer in the presence of a germline $B R C A$ mutation. The ongoing LUCY registry study is an open label single arm multicentre study evaluating the effectiveness of olaparib in improving PFS in patients with metastatic breast cancer and either a germline or somatic $B R C A$ mutation $^{115}$.

The benefit of adjuvant PARPis in $B R C A$-mutated early breast cancer, however, remains to be proven and is under investigation in the ongoing OlympiA trial, the results of which are awaited $^{116}$.

A number of trials have investigated the potential benefit of PARPis in patients with unselected (BRCA wild-type or unknown mutation status) TNBC, hypothesising that a proportion of these tumours may harbour an HRD and thus the synthetic lethality resulting from PARP inhibition may be clinically beneficial. The NOBROLA, RUBY and TBB trials are phase II studies in advanced breast cancer evaluating olaparib, rucaparib and talazoparib respectively ${ }^{117-119}$, with the first two studies showing some evidence of efficacy and the third ongoing. In early disease, the I-SPY2 study assessed the combination of neoadjuvant veliparib and carboplatin, reporting a pCR rate for this combination of $51 \%$, compared with $26 \%$ in controls ${ }^{121}$. In contrast, the BrighTNess trial (comparing paclitaxel alone, paclitaxel plus carboplatin or paclitaxel, carboplatin and veliparib in unselected stage II-III TNBC) showed that while there was an increased pCR rate with the addition of carboplatin to 
paclitaxel (31\% vs 58\%), no additional benefit was gained from adding PARP inhibition (pCR rate $53 \%$ in the veliparib arm) ${ }^{120}$.

As a proportion of patients did not respond to PARPis in the OlympiAD and EMBRACA trials and the observed toxicities, it may be beneficial to refine groups of patients based on HRD status - who may be expected to derive an increased benefit from such therapies. Indeed, in the past 3 years, trials have been set-up to investigate this by incorporating HRD status into the inclusion criteria when assessing PARPi efficacy. These trials also tested these in non- $B R C A$ breast cancers and are important as they can reveal roles of the other HR genes (carriers with HRD but no BRCA mutations are termed as 'BRCAness'). Indeed, it has been shown that deficiencies in RAD51, ATM and CHK2 can induce sensitivity to PARPis ${ }^{109}$.

Clearly then there is a requirement to identify breast cancers with an HRD, in order to exploit this therapeutically, and several putative biomarkers have been developed with this aim.

Indeed, there is significant data suggesting that the Myriad HRD assay discussed above may be predictive of patient benefit in the clinical setting. In addition, the HRDetect assay developed by Davies et al in 2014 was suggested to reveal a larger proportion of individual breast cancer patients with $B R C A 1 / 2$ deficiency than previously appreciated, who may benefit from PARP inhibition ${ }^{122}$.

The concept of 'BRCAness' has also been used to describe tumours with a potential HRD in the absence of a germline $B R C A 1 / 2$ mutation. In such tumours, mutations in other HR genes, methylation of the $B R C A 1 / 2$ (and perhaps other HR gene) promoters, or reduced expression of these genes via transcriptional regulation may explain an HRD when no mutations are identified $^{123}$. Indeed, non- $B R C A$ HR gene mutated TNBCs were shown to share some of the 'BRCAness' features, such as a higher number and length of structural aberrations and may also benefit from PARP-inhibition ${ }^{124}$. 
A further potential biomarker for HRD has been described in the DNA Damage Response Deficiency) DDRD signature. This 44-gene, expression-based assay was developed using bone marrow derived from Fanconi Anaemia (FA) patients and from a cohort of $B R C A$ mutant enriched breast cancers. This signature identified a subgroup of patients with a DDR deficiency (DDRD), characterised by upregulation of immune processes and as a result the assay has since been renamed the DNA Damage Immune Response (DDIR) assay ${ }^{125}$. This signature has been validated as predictive of response to DNA-damaging chemotherapeutic agents in both the adjuvant and neoadjuvant settings ${ }^{104,125}$ and may have an advantage over other assays as it is reflective of the current biological response to HR deficiency within a tumour. In contrast, the HR assays discussed above, which detect genomic scarring caused by HRD, detect the non-reversible and heritable end-product of a HRD, which may be more reflective of tumour evolutionary history rather than current tumour biology. Indeed, a number of reports have demonstrated that $B R C A 1 / 2$ deficient HRD tumours can acquire further "reversion" mutations in BRCA1/2 to become platinum and/or PARPi resistant, HR proficient, tumours. Whilst HR proficient, these tumours still harbour the genomic scars of their evolutionary HRD (the role of reversion mutations is discussed in further detail below). Interestingly, further investigation of the underpinning mechanism of the DDIR suggests that this may be directly linked to HRD, through accumulation of unrepaired/damaged DNA in the cytoplasm of HRD cells, resulting in activation of the cGAS/STING pathway. Sensing of cytosolic dsDNA by cGAS (Cyclic GMP-AMP (cGAMP) synthase) results in cGAMP production triggering, STING (stimulator of interferon genes) activation, causing activation of an IRF3/TBK1 dependent Type I interferon transcriptional cascade ${ }^{126-128}$. This includes the upregulation of both chemokines and immune checkpointing genes, creating an "inflamed yet immunosuppressed" tumour microenvironment. This is borne out by the fact that the DDIR assay score has been shown to correlate with tumour infiltrating lymphocytes (TILs), yet in 
the SWOG validation study by Sharma et al, DDIR outperformed TIL scoring in predicting response to adjuvant anthracycline chemotherapy ${ }^{104}$.

Consequently, this assay provides a biomarker to identify breast cancers with an HRD where there is upregulation of immune checkpointing genes, which may then respond to treatment with immune checkpoint blockade, possibly in combination with DNA damaging agents. In line with this, Pantelidou et al have shown PARPi efficacy in BRCA mutant mouse models is dependent upon the STING pathway immune response ${ }^{129}$. Additionally, early phase clinical work in the MEDIOLA basket trial has demonstrated anti-tumour activity for the combination of olaparib and durvulumab (a PD-L1 inhibitor) in germline $B R C A$-mutated advanced breast cancer ${ }^{130}$. Furthermore, in the I-SPY 2 trial the use of this combination, together with paclitaxel, followed by doxorubicin/cyclophosphamide in the neoadjuvant setting in both high risk ER- and ER+ early breast cancer resulted in an estimated pCR rate of $37 \%$, compared with $20 \%$ in patients receiving paclitaxel-adriamycin/cyclophosphamide chemotherapy alone ${ }^{131}$.

In conclusion, it is clear that a proportion of breast cancers harbour an HRD and this offers the opportunity to personalise treatment approaches, whether by selection of appropriate systemic cytotoxic chemotherapy, or the use of other targeted agents such as PARPis or immune checkpoint blockade. However, there remain challenges in identifying optimal treatment options and there clearly remains a need to better understand the interaction between HRD and therapeutics, and for improved biomarkers to advance treatment selection in these patients. 


\section{Challenges and future perspectives}

It is clear from the above that HRD contributes significantly to breast cancer risk, tumour development and progression, and is also vulnerable to exploitation for therapeutic benefit in the clinical setting. Several studies have shown clinical activity of agents targeting HRD, such as platinums and PARPis, in both early and metastatic breast cancer, as discussed earlier. It is clear, however, that there remain significant challenges in the precision treatment of such cancers. Self-evidently, for agents targeting HR pathways, there needs to be clear evidence of HRD for these drugs to be effective. However, as the clinical data shows, there is no robust, reliable biomarker which accurately identifies tumours with an HRD, to allow treatment selection in the clinic. Although the Myriad HRD assay, and HRDetect have shown promise in this regard, the conflicting data reported above suggests that there is a need for better and more reliable biomarkers. In particular, these assays identify genomic scarring and therefore may be more reflective of the previous history of a cancer and its treatment, rather than its current biology. Furthermore, studies in advanced disease have used primary tumour tissue for these assays and it is known that primary tumour phenotype is not necessarily reflective of the biology of metastatic disease ${ }^{132}$. Thus, it is perhaps unsurprising that the use of such assays in this manner is not predictive of outcome in advanced disease. It has been demonstrated that the genomic landscape of metastatic breast cancer is significantly more disordered than early disease and that such changes may occur under treatment selection pressures ${ }^{133}$. One potential explanation for resistance to targeted therapies may lie in the development of reversion mutations that restore DDR functions such 
as HR. Such reversion mutations can restore the gene reading frame and remove a priorexisting deleterious alteration, and may be substitutions, insertions or deletions ${ }^{134}$. For example, reversion mutations in $B R C A 1 / 2$ have been shown to partially restore WT gene function $^{135,136}$. Additionally, mutations and/or downregulation of other genes with roles in preventing HR may also restore HR activity in HRD tumours. For example, mutations in the genes encoding 53BP1 and REV7 and downregulated 53BP1 expression have been identified in PARPi resistant in BRCA1 -/- breast tumours ${ }^{137-139} .53 \mathrm{BP} 1$ functions along with Rif1 and Rev7 to recruit the shieldin complex to DSB ends, where it functions to prevent end resection and promote NHEJ mediated DSB repair ${ }^{140-143}$. BRCA1 functions to oppose this and has been shown to remodel 53BP1 away from DSB ends, thus presumably preventing shieldin binding and facilitating DNA end resection and HR. Indeed, loss of any of the key components of this pathway have been shown to restore DNA end resection and RAD51 loading in BRCA1 deficient cells, suggesting that mutations and/or loss downregulated expression of any of these genes may play a role in drug resistance and HR restoration in HRD tumours and clouding the use of genomic scarring assays for HRD assessment and treatment selection.

It is possible that assays such as the DDIR assay, which are reflective of current, rather than historical tumour biology, may point the way forward, both in terms of identifying patients with an HRD likely to respond to DNA-damaging targeted therapies and which may also respond to immune checkpoint blockade due to upregulation of the DNA damage driven immune response described earlier. However, additional clinical validation of this assay is awaited.

In conclusion, HRD remains a key therapeutic target in breast cancer, and there is a pressing clinical need to develop robust, validated biomarkers identifying HRD tumours which will respond to targeted therapies. It is highly likely that the optimal setting for targeting HRD is 
in the early disease setting (either neoadjuvant or adjuvant), potentially with combination therapies, to ensure maximal tumour cell eradication before resistance mechanisms, such as reversion mutations, have the opportunity to arise from the genomic disorder of advanced disease.

\section{References}

1. Jackson SP, Bartek J. The DNA-damage response in human biology and disease. Nature. 2009;461(7267):1071-1078.

2. Orr KS, Savage KI. The BRCA1 and BRCA2 Breast and Ovarian Cancer Susceptibility Genes - Implications for DNA Damage Response, DNA Repair and Cancer Therapy. In C.C. Chen (Ed). Advances in DNA Repair. 2015. IntechOpen.

https://www.intechopen.com/books/advances-in-dna-repair/the-brca1-and-brca2-breast-andovarian-cancer-susceptibility-genes-implications-for-dna-damage-respo. Accessed October $16,2020$.

3. Negrini S, Gorgoulis VG, Halazonetis TD. Genomic instability - an evolving hallmark of cancer. Nat Rev Mol Cell Biol. 2010;11(3):220-228.

4. Hanahan D, Weinberg RA. Hallmarks of cancer: the next generation. Cell. 2011;144(5):646-674.

5. den Brok WD, Schrader KA, Sun, S, et al. Homologous Recombination Deficiency in Breast Cancer: A Clinical Review. JCO Precision Oncology. 2017;1:1-13. https://ascopubs.org/doi/full/10.1200/PO.16.00031. Accessed October 16, 2020.

6. Lafrance-Vanasse J, Williams GJ, Tainer JA. Envisioning the dynamics and flexibility of Mre11-Rad50-Nbs1 complex to decipher its roles in DNA replication and repair. Prog Biophys Mol Biol. 2015;117(2-3):182-193. 
7. Lee JH, Paull TT. ATM activation by DNA double-strand breaks through the Mre11Rad50-Nbs1 complex [published correction appears in Science. 2005 Jun 24;308(5730):1870]. Science. 2005;308(5721):551-554.

8. Matsuoka S, Rotman G, Ogawa A, Shiloh Y, Tamai K, Elledge SJ. Ataxia telangiectasiamutated phosphorylates Chk2 in vivo and in vitro. Proc Natl Acad Sci U S A. 2000;97(19):10389-10394.

9. Kumagai A, Kim SM, Dunphy WG. Claspin and the activated form of ATR-ATRIP collaborate in the activation of Chk1. J Biol Chem. 2004 Nov 26;279(48):49599-608. https://pubmed.ncbi.nlm.nih.gov/15371427/. Accessed November 07, 2020.

10. Gatei M, Sloper K, Sorensen C, et al. Ataxia-telangiectasia-mutated (ATM) and NBS1dependent phosphorylation of Chk1 on Ser-317 in response to ionizing radiation. J Biol Chem. 2003;278(17):14806-14811.

11. Parameswaran B, Chiang HC, Lu Y, et al. Damage-induced BRCA1 phosphorylation by Chk2 contributes to the timing of end resection. Cell Cycle. 2015;14(3):437-448.

12. Yu X, Chen J. DNA damage-induced cell cycle checkpoint control requires CtIP, a phosphorylation-dependent binding partner of BRCA1 C-terminal domains. Mol Cell Biol. 2004;24(21):9478-9486.

13. Zhao W, Wiese C, Kwon Y, Hromas R, Sung P. The BRCA Tumor Suppressor Network in Chromosome Damage Repair by Homologous Recombination. Annu Rev Biochem. 2019;88:221-245.

14. Scully R, Chen J, Plug A, et al. Association of BRCA1 with Rad51 in mitotic and meiotic cells. Cell. 1997;88(2):265-275. 
15. Scully R, Ganesan S, Vlasakova K, Chen J, Socolovsky M, Livingston DM. Genetic analysis of BRCA1 function in a defined tumor cell line. Mol Cell. 1999;4(6):1093-1099.

16. Moynahan ME, Chiu JW, Koller BH, Jasin M. Brca1 controls homology-directed DNA repair. Mol Cell. 1999;4(4):511-518.

17. Holloman WK. Unraveling the mechanism of BRCA2 in homologous recombination. Nat Struct Mol Biol. 2011;18(7):748-754.

18. Jensen RB, Carreira A, Kowalczykowski SC. Purified human BRCA2 stimulates RAD51-mediated recombination. Nature. 2010;467(7316):678-683.

19. Yang H, Jeffrey PD, Miller J, et al. BRCA2 function in DNA binding and recombination from a BRCA2-DSS1-ssDNA structure. Science. 2002;297(5588):1837-1848.

20. Connor F, Bertwistle D, Mee PJ, et al. Tumorigenesis and a DNA repair defect in mice with a truncating Brca2 mutation. Nat Genet. 1997;17(4):423-430.

21. Sharan SK, Morimatsu M, Albrecht U, et al. Embryonic lethality and radiation hypersensitivity mediated by Rad51 in mice lacking Brca2. Nature. 1997;386(6627):804-810.

22. Polak P, Kim J, Braunstein LZ, et al. A mutational signature reveals alterations underlying deficient homologous recombination repair in breast cancer. Nat Genet. 2017;49(10):1476-1486.

23. Staaf J, Glodzik D, Bosch A, et al. Whole-genome sequencing of triple-negative breast cancers in a population-based clinical study. Nat Med. 2019;25(10):1526-1533. 
24. Birkbak NJ, Wang ZC, Kim JY, et al. Telomeric allelic imbalance indicates defective DNA repair and sensitivity to DNA-damaging agents [published correction appears in Cancer Discov. 2013 Aug;3(8):952]. Cancer Discov. 2012;2(4):366-375.

25. Abkevich V, Timms K, Hennessy B, et al. Patterns of genomic loss of heterozygosity predict homologous recombination repair defects in epithelial ovarian cancer. Br J Cancer. 2012;107:1776-1782.

26. Popova T, Manié E, Rieunier G, et al. Ploidy and large-scale genomic instability consistently identify basal-like breast carcinomas with BRCA1/2 inactivation. Cancer Res. 2012;72(21):5454-5462.

27. Cavenee WK, Dryja TP, Phillips RA, et al. Expression of recessive alleles by chromosomal mechanisms in retinoblastoma. Nature. 1983;305(5937):779-784.

28. Miller BJ, Wang D, Krahe R, Wright FA. Pooled analysis of loss of heterozygosity in breast cancer: a genome scan provides comparative evidence for multiple tumor suppressors and identifies novel candidate regions. Am J Hum Genet. 2003;73(4):748-767.

29. Petrucelli N, Daly MB, Feldman GL. Hereditary breast and ovarian cancer due to mutations in BRCA1 and BRCA2. Genet Med. 2010;12(5):245-259.

30. Malone KE, Daling JR, Doody DR, et al. Prevalence and predictors of BRCA1 and BRCA2 mutations in a population-based study of breast cancer in white and black American women ages 35 to 64 years. Cancer Res. 2006;66(16):8297-8308.

31. Antoniou AC, Cunningham AP, Peto J, et al. The BOADICEA model of genetic susceptibility to breast and ovarian cancers: updates and extensions. $\mathrm{Br} J$ Cancer. 2008;98(8):1457-1466. 
32. Slavin TP, Maxwell KN, Lilyquist J, et al. The contribution of pathogenic variants in breast cancer susceptibility genes to familial breast cancer risk [published correction appears in NPJ Breast Cancer. 2017 Nov 7;3:44]. NPJ Breast Cancer. 2017;3:22.

33. Ford D, Easton DF, Stratton M. et al. Genetic heterogeneity and penetrance analysis of the BRCA1 and BRCA2 genes in breast cancer families. The Breast Cancer Linkage Consortium. Am J Hum Genet. 1998;62(3):676-689.

34. Antoniou A, Pharoah PD, Narod S, et al. Average risks of breast and ovarian cancer associated with BRCA1 or BRCA2 mutations detected in case Series unselected for family history: a combined analysis of 22 studies. Am J Hum Genet. 2003;72(5):1117-1130.

35. King MC, Marks JH, Mandell JB. Breast and ovarian cancer risks due to inherited mutations in BRCA1 and BRCA2. Science. 2003;302(5645):643-646.

36. Garber JE, Goldstein AM, Kantor AF, Dreyfus MG, Fraumeni JFJ, Li FP. Follow-up Study of Twenty-four Families with Li-Fraumeni Syndrome. Cancer Res. 1991;51(22):60946097.

37. Birch JM, Alston RD, McNally RJ, et al. Relative frequency and morphology of cancers in carriers of germline TP53 mutations. Oncogene. 2001;20(34):4621-4628.

38. Nelen MR, Padberg GW, Peeters EAJ, et al. Localization of the gene for Cowden disease to chromosome 10q22-23. Nat Genet. 1996;13(1):114-116.

39. Kechagioglou P, Papi RM, Provatopoulou X, et al. Tumor suppressor PTEN in breast cancer: heterozygosity, mutations and protein expression. Anticancer Res. 2014;34(3):13871400.

40. Rahman N, Seal S, Thompson D, et al. PALB2, which encodes a BRCA2-interacting protein, is a breast cancer susceptibility gene. Nat Genet. 2007;39(2):165-167. 
41. Fernandes PH, Saam J, Peterson J, et al. Comprehensive sequencing of PALB2 in patients with breast cancer suggests PALB2 mutations explain a subset of hereditary breast cancer. Cancer. 2014;120(7):963-967.

42. Antoniou AC, Casadei S, Heikkinen T, et al. Breast-cancer risk in families with mutations in PALB2. $N$ Engl J Med. 2014;371(6):497-506.

43. Meijers-Heijboer H, van den Ouweland A, Klijn J, et al. Low-penetrance susceptibility to breast cancer due to CHEK2(*)1100delC in noncarriers of BRCA1 or BRCA2 mutations. Nat Genet. 2002;31(1):55-59.

44. Desrichard A, Bidet Y, Uhrhammer N, Bignon YJ. CHEK2 contribution to hereditary breast cancer in non-BRCA families. Breast Cancer Res. 2011;13(6):R119.

45. Thompson D, Duedal S, Kirner J, et al. Cancer risks and mortality in heterozygous ATM mutation carriers. J Natl Cancer Inst. 2005;97(11):813-822.

46. Renwick A, Thompson D, Seal S, et al. ATM mutations that cause ataxia-telangiectasia are breast cancer susceptibility alleles. Nat Genet. 2006;38(8):873-875.

47. Cantor S, Drapkin R, Zhang F, et al. The BRCA1-associated protein BACH1 is a DNA helicase targeted by clinically relevant inactivating mutations. Proc Natl Acad Sci US A. 2004;101(8):2357-2362.

48. Seal S, Thompson D, Renwick A, et al. Truncating mutations in the Fanconi anemia $\mathbf{J}$ gene BRIP1 are low-penetrance breast cancer susceptibility alleles. Nat Genet. 2006;38(11):1239-1241.

49. Mavaddat N, Antoniou AC, Easton DF, Garcia-Closas M. Genetic susceptibility to breast cancer. Mol Oncol. 2010;4(3):174-191. 
50. Thompson ER, Rowley SM, Li N, et al. Panel Testing for Familial Breast Cancer:

Calibrating the Tension Between Research and Clinical Care. J Clin Oncol.

2016;34(13):1455-1459.

51. Hollestelle A, Wasielewski M, Martens JW, Schutte M. Discovering moderate-risk breast cancer susceptibility genes. Curr Opin Genet Dev. 2010;20(3):268-276.

52. De Leeneer K, Van Bockstal M, De Brouwer S, et al. Evaluation of RAD51C as cancer susceptibility gene in a large breast-ovarian cancer patient population referred for genetic testing. Breast Cancer Res Treat. 2012;133(1):393-398.

53. Le Calvez-Kelm F, Oliver J, Damiola F, et al. RAD51 and breast cancer susceptibility: no evidence for rare variant association in the Breast Cancer Family Registry study. PLoS One. 2012;7(12):e52374.

https://journals.plos.org/plosone/article?id=10.1371/journal.pone.0052374. Accessed October $20,2020$.

54. Jønson L, Ahlborn LB, Steffensen AY, et al. Identification of six pathogenic RAD51C mutations via mutational screening of 1228 Danish individuals with increased risk of hereditary breast and/or ovarian cancer. Breast Cancer Res Treat. 2016;155(2):215-222.

55. Wong MW, Nordfors C, Mossman D, et al. BRIP1, PALB2, and RAD51C mutation analysis reveals their relative importance as genetic susceptibility factors for breast cancer. Breast Cancer Res Treat. 2011;127(3):853-859.

56. Li W, Liu KJ, Song JS, Song R, Liu ZL. Association between RAD51 polymorphism and breast cancer susceptibility: a meta analysis. Int J Clin Exp Med. 2015;8(2):2326-2333.

57. Korak T, Ergül E, Üren N, et al. RAD51 (rs1801320) gene polymorphism and breast cancer risk in Turkish population. Int J Clin Exp Pathol. 2017;10(2):2181-2186. 
58. Kurian AW, Hughes E, Handorf EA, et al. Breast and Ovarian Cancer Penetrance Estimates Derived From Germline Multiple-Gene Sequencing Results in Women. JCO Precision Oncology. 2017;1:1-12. https://ascopubs.org/doi/10.1200/PO.16.00066. Accessed October 20, 2020.

59. Hays SL, Firmenich AA, Berg P. Complex formation in yeast double-strand break repair: Participation of Rad51, Rad52, Rad55, and Rad57 proteins. Proc Natl Acad Sci U S A. 1995;92(15):6925-6929.

60. Johnson RD, Symington LS. Functional Differences and Interactions among the Putative RecA Homologs Rad51, Rad55, and Rad57. Mol Cell Biol. 1995;15(9):4843-4850.

61. Fujimori A, Tachiiri S, Sonoda E, et al. Rad52 partially substitutes for the Rad51 paralog XRCC3 in maintaining chromosomal integrity in vertebrate cells. EMBO J. 2001;20(19):5513-5520.

62. Takata M, Sasaki MS, Tachiiri S, et al. Chromosome instability and defective recombinational repair in knockout mutants of the five Rad51 paralogs. Mol Cell Biol. $2001 ; 21(8): 2858-2866$.

63. Klein HL. The consequences of Rad51 overexpression for normal and tumor cells. DNA Repair (Amst). 2008;7(5):686-693.

64. Maacke H, Opitz S, Jost K, et al. Over-expression of wild-type Rad51 correlates with histological grading of invasive ductal breast cancer. Int J Cancer. 2000;88(6):907-913.

65. Richardson C, Stark JM, Ommundsen M, Jasin M. Rad51 overexpression promotes alternative double-strand break repair pathways and genome instability. Oncogene. 2004;23(2):546-553. 
66. Rosai J, Ackerman LV. Rosai and Ackerman's surgical pathology. Philadelphia, Elsevier, 2011.

67. Pegram MD, Pienkowski T, Northfelt DW, et al. Results of two open-label, multicenter phase II studies of docetaxel, platinum salts, and trastuzumab in HER2-positive advanced breast cancer. J Natl Cancer Inst. 2004;96(10):759-769.

68. Tripathy D, Slamon DJ, Cobleigh M, et al. Safety of treatment of metastatic breast cancer with trastuzumab beyond disease progression. J Clin Oncol. 2004;22(6):1063-1070.

69. Robert N, Leyland-Jones B, Asmar L, et al. Randomized phase III study of trastuzumab, paclitaxel, and carboplatin compared with trastuzumab and paclitaxel in women with HER-2overexpressing metastatic breast cancer. J Clin Oncol. 2006;24(18):2786-2792.

70. Chen H, Wu J, Zhang Z, et al. Association Between BRCA Status and Triple-Negative Breast Cancer: A Meta-Analysis. Front Pharmacol. 2018;9:909.

71. Hu C, Polley EC, Yadav S, et al. The contribution of germline predisposition gene mutations to clinical subtypes of invasive breast cancer from a clinical genetic testing cohort [published online ahead of print, 2020 Feb 24]. J Natl Cancer Inst. 2020;djaa023. https://academic.oup.com/jnci/advance-article/doi/10.1093/jnci/djaa023/5753953. Accessed October 20, 2020.

72. Williams AB, Schumacher B. p53 in the DNA-Damage-Repair Process. Cold Spring Harb Perspect Med. 2016;6(5):a026070. Published 2016 May 2. https://www.ncbi.nlm.nih.gov/pmc/articles/PMC4852800/. Accessed October 20, 2020. 73. Shimelis H, LaDuca H, Hu C, et al. Triple-Negative Breast Cancer Risk Genes Identified by Multigene Hereditary Cancer Panel Testing. J Natl Cancer Inst. 2018;110(8):855-862. 
74. Levine MN, Pritchard KI, Bramwell VH, et al. Randomized trial comparing cyclophosphamide, epirubicin, and fluorouracil with cyclophosphamide, methotrexate, and fluorouracil in premenopausal women with node-positive breast cancer: update of National Cancer Institute of Canada Clinical Trials Group Trial MA5. J Clin Oncol. 2005;23(22):5166-5170.

75. Hortobagyi GN, Ames FC, Buzdar AU, et al. Management of stage III primary breast cancer with primary chemotherapy, surgery, and radiation therapy. Cancer. $1988 ; 62(12): 2507-2516$.

76. Bull JM, Tormey DC, Li SH, et al. A randomized comparative trial of adriamycin versus methotrexate in combination drug therapy. Cancer. 1978;41(5):1649-1657.

77. Hutchins LF, Green SJ, Ravdin PM, et al. Randomized, controlled trial of cyclophosphamide, methotrexate, and fluorouracil versus cyclophosphamide, doxorubicin, and fluorouracil with and without tamoxifen for high-risk, node-negative breast cancer: treatment results of Intergroup Protocol INT-0102. J Clin Oncol. 2005;23(33):8313-8321.

78. French Adjuvant Study Group. Benefit of a high-dose epirubicin regimen in adjuvant chemotherapy for node-positive breast cancer patients with poor prognostic factors: 5-year follow-up results of French Adjuvant Study Group 05 randomized trial. J Clin Oncol. 2001;19(3):602-611.

79. Early Breast Cancer Trialists' Collaborative Group (EBCTCG), Peto R, Davies C, et al. Comparisons between different polychemotherapy regimens for early breast cancer: metaanalyses of long-term outcome among 100,000 women in 123 randomised trials. Lancet. 2012;379(9814):432-444.

80. Gianni L, Baselga J, Eiermann W, et al. Phase III trial evaluating the addition of paclitaxel to doxorubicin followed by cyclophosphamide, methotrexate, and fluorouracil, as 
adjuvant or primary systemic therapy: European Cooperative Trial in Operable Breast Cancer. J Clin Oncol. 2009;27(15):2474-2481.

81. Wani MC, Taylor HL, Wall ME, Coggon P, McPhail AT. Plant antitumor agents. VI. The isolation and structure of taxol, a novel antileukemic and antitumor agent from Taxus brevifolia. J Am Chem Soc. 1971;93(9):2325-2327.

82. Harkin DP, Bean JM, Miklos D, et al. Induction of GADD45 and JNK/SAPK-Dependent Apoptosis following Inducible Expression of BRCA1. Cell. 1999;97(5):575-586.

83. Thangaraju M, Kaufmann SH, Couch FJ. BRCA1 facilitates stress-induced apoptosis in breast and ovarian cancer cell lines. J Biol Chem. 2000;275(43):33487-33496.

84. Byrski T, Huzarski T, Dent R, et al. Response to neoadjuvant therapy with cisplatin in BRCA1-positive breast cancer patients. Breast Cancer Res Treat. 2009;115(2):359-363.

85. Wen J, Li R, Lu Y, Shupnik MA. Decreased BRCA1 confers tamoxifen resistance in breast cancer cells by altering estrogen receptor-coregulator interactions. Oncogene. 2009;28(4):575-586.

86. Byrski T, Gronwald J, Huzarski T, et al. Pathologic complete response rates in young women with BRCA1-positive breast cancers after neoadjuvant chemotherapy. J Clin Oncol. 2010;28(3):375-379.

87. Sæther NH, Skuja E, Irmejs A, et al. Platinum-based neoadjuvant chemotherapy in BRCA1-positive breast cancer: a retrospective cohort analysis and literature review. Hered Cancer Clin Pract. 2018;16:9.

88. Chen X, Wu Y, Dong H, Zhang CY, Zhang Y. Platinum-based agents for individualized cancer treatment. Curr Mol Med. 2013;13(10):1603-1612. 
89. Quinn JE, Kennedy RD, Mullan PB, et al. BRCA1 functions as a differential modulator of chemotherapy-induced apoptosis. Cancer Res. 2003;63(19):6221-6228.

90. Bhattacharyya A, Ear US, Koller BH, Weichselbaum RR, Bishop DK. The breast cancer susceptibility gene BRCA1 is required for subnuclear assembly of Rad51 and survival following treatment with the DNA cross-linking agent cisplatin. $J$ Biol Chem.

2000;275(31):23899-23903.

91. Moynahan ME, Cui TY, Jasin M. Homology-directed dna repair, mitomycin-c resistance, and chromosome stability is restored with correction of a Brcal mutation. Cancer Res. 2001;61(12):4842-4850.

92. Tassone P, Tagliaferri P, Perricelli A, et al. BRCA1 expression modulates chemosensitivity of BRCA1-defective HCC1937 human breast cancer cells. Br J Cancer. $2003 ; 88(8): 1285-1291$.

93. Fedier A, Steiner RA, Schwarz VA, Lenherr L, Haller U, Fink D. The effect of loss of Brcal on the sensitivity to anticancer agents in p53-deficient cells. Int J Oncol. 2003;22(5):1169-1173.

94. Bartz SR, Zhang Z, Burchard J, et al. Small interfering RNA screens reveal enhanced cisplatin cytotoxicity in tumor cells having both BRCA network and TP53 disruptions. Mol Cell Biol. 2006;26(24):9377-9386.

95. Donoho G, Brenneman MA, Cui TX, et al. Deletion of Brca2 exon 27 causes hypersensitivity to DNA crosslinks, chromosomal instability, and reduced life span in mice. Genes Chromosomes Cancer. 2003;36(4):317-331.

96. Kim TM, Son MY, Dodds S, Hu L, Hasty P. Deletion of BRCA2 exon 27 causes defects in response to both stalled and collapsed replication forks. Mutat Res. 2014;766-767:66-72. 
97. Tassone P, Di Martino MT, Ventura M, et al. Loss of BRCA1 function increases the antitumor activity of cisplatin against human breast cancer xenografts in vivo. Cancer Biol Ther. 2009;8(7):648-653.

98. Yuan SS, Lee SY, Chen G, Song M, Tomlinson GE, Lee EY. BRCA2 is required for ionizing radiation-induced assembly of Rad51 complex in vivo. Cancer Res. $1999 ; 59(15): 3547-3551$.

99. Byrski T, Huzarski T, Dent R, et al. Pathologic complete response to neoadjuvant cisplatin in BRCA1-positive breast cancer patients. Breast Cancer Res Treat. 2014;147(2):401-405.

100. Telli ML, Jensen KC, Vinayak S, et al. Phase II Study of Gemcitabine, Carboplatin, and Iniparib As Neoadjuvant Therapy for Triple-Negative and BRCA1/2 Mutation-Associated Breast Cancer With Assessment of a Tumor-Based Measure of Genomic Instability: PrECOG 0105. J Clin Oncol. 2015;33(17):1895-1901.

101. Loibl S, Weber KE, Timms KM, et al. Survival analysis of carboplatin added to an anthracycline/taxane-based neoadjuvant chemotherapy and HRD score as predictor of response-final results from GeparSixto. Ann Oncol. 2018;29(12):2341-2347.

102. Mayer EL, Abramson V, Jankowitz R, et al. TBCRC 030: a phase II study of preoperative cisplatin versus paclitaxel in triple-negative breast cancer: evaluating the homologous recombination deficiency (HRD) biomarker [published online ahead of print, 2020 Aug 13]. Ann Oncol. 2020;S0923-7534(20)42061-7.

https://ascopubs.org/doi/10.1200/JCO.2019.37.15_suppl.507. Accessed October 31, 2020. 103. Tutt A, Tovey H, Cheang MCU, et al. Carboplatin in BRCA1/2-mutated and triplenegative breast cancer BRCAness subgroups: the TNT Trial. Nat Med. 2018;24(5):628-637. 
104. Sharma P, Barlow WE, Godwin AK, et al. Impact of homologous recombination deficiency biomarkers on outcomes in patients with triple-negative breast cancer treated with adjuvant doxorubicin and cyclophosphamide (SWOG S9313). Ann Oncol. 2018;29(3):654660.

105. Abkevich V, Timms KM, Hennessy BT, et al. Patterns of genomic loss of heterozygosity predict homologous recombination repair defects in epithelial ovarian cancer. Br J Cancer. 2012;107(10):1776-1782.

106. Pandy JGP, Balolong-Garcia JC, Cruz-Ordinario MVB, Que FVF. Triple negative breast cancer and platinum-based systemic treatment: a meta-analysis and systematic review. BMC Cancer. 2019;19(1):1065.

107. Farmer H, McCabe N, Lord CJ, et al. Targeting the DNA repair defect in BRCA mutant cells as a therapeutic strategy. Nature. 2005;434(7035):917-921.

108. Bryant HE, Schultz N, Thomas HD, et al. Specific killing of BRCA2-deficient tumours with inhibitors of poly(ADP-ribose) polymerase [published correction appears in Nature. 2007 May 17;447(7142):346]. Nature. 2005;434(7035):913-917.

109. McCabe N, Turner NC, Lord CJ, et al. Deficiency in the repair of DNA damage by homologous recombination and sensitivity to poly(ADP-ribose) polymerase inhibition. Cancer Res. 2006;66(16):8109-8115.

110. Tung N M, Garber JE. BRCA1/2 testing: therapeutic implications for breast cancer management. Br J Cancer. 2018;119(2):141-152.

111. Tutt A, Robson M, Garber JE, et al. Oral poly(ADP-ribose) polymerase inhibitor olaparib in patients with BRCA1 or BRCA2 mutations and advanced breast cancer: a proofof-concept trial. The Lancet. 2010;376(9737):235-244. 
112. Robson M, Im SA, Senkus E, et al. Olaparib for Metastatic Breast Cancer in Patients with a Germline BRCA Mutation [published correction appears in N Engl J Med. 2017 Oct 26;377(17 ):1700]. N Engl J Med. 2017;377(6):523-533.

113. Litton JK, Rugo HS, Ettl J, et al. Talazoparib in Patients with Advanced Breast Cancer and a Germline BRCA Mutation. N Engl J Med. 2018;379(8):753-763.

114. Diéras V, Han HS, Kaufman B, et al. Veliparib with carboplatin and paclitaxel in BRCA-mutated advanced breast cancer (BROCADE3): a randomised, double-blind, placebocontrolled, phase 3 trial. Lancet Oncol. 2020;21(10):1269-1282.

115. Gelmon KA, Walker GP, Fisher GV, McCutcheon SC. LUCY: A phase IIIb, real-world study of olaparib in HER2-negative metastatic breast cancer patients with a BRCA mutation [Abstract 367TiP]. Ann. Oncol. 2018;29(8_suppl):viii90-viii121. https://doi.org/10.1093/annonc/mdy272.355. Accessed: 01 November, 2020.

116. Tutt A, Kaufman B, Garber J, et al. OlympiA: A randomized phase III trial of olaparib as adjuvant therapy in patients with high-risk HER2-negative breast cancer (BC) and a germline BRCA1/2 mutation (gBRCAm) [Abstract 216TiP]. Ann. Oncol. 2017;28(5_suppl):67. https://doi.org/10.1093/annonc/mdx362.065. Accessed: 09 November, 2020.

117. Aguirre E, Amillano K, Cortés A, et al. A two-stage Simon Design phase II study for NOn-BRCA metastatic BReast cancer (MBC) patients with homologous recombination deficiency treated with OLAparib single agent.(NOBROLA study) [Abstract CT165]. Cancer Res. 2018;78(13_suppl):CT165.

https://cancerres.aacrjournals.org/content/78/13_Supplement/CT165. Accessed: 09 November, 2020. 
118. Patsouris A, Tredan O, Nenciu D, et al. RUBY: A phase II study testing rucaparib in germline (g) BRCA wild-type patients presenting metastatic breast cancer (mBC) with homologous recombination deficiency (HRD) [Abstract 1092]. J Clin Oncol. 2019;37(15_suppl):1092. https://ascopubs.org/doi/abs/10.1200/JCO.2019.37.15_suppl.1092. Accessed: 09 November, 2020.

119. Gruber JJ, Afghahi A, Hatton A, et al. Talazoparib beyond BRCA: A phase II trial of talazoparib monotherapy in BRCA1 and BRCA2 wild-type patients with advanced HER2negative breast cancer or other solid tumors with a mutation in homologous recombination (HR) pathway genes [Abstract 3006]. J Clin Oncol. 2019;37(15_suppl):3006. https://ascopubs.org/doi/abs/10.1200/JCO.2019.37.15_suppl.3006. Accessed: 09 November, 2020.

120. Loibl S, O'Shaughnessy J, Untch M, et al. Addition of the PARP inhibitor veliparib plus carboplatin or carboplatin alone to standard neoadjuvant chemotherapy in triple-negative breast cancer (BrighTNess): a randomised, phase 3 trial. Lancet Oncol. 2018;19(4):497-509.

121. Rugo HS, Olopade OI, DeMichele A, et al. Adaptive Randomization of VeliparibCarboplatin Treatment in Breast Cancer. N Engl J Med. 2016;375(1):23-34.

122. Davies H, Glodzik D, Morganella S, et al. HRDetect is a predictor of BRCA1 and BRCA2 deficiency based on mutational signatures. Nat Med. 2017;23(4):517-525.

123. Turner N, Tutt A, Ashworth A. Hallmarks of 'BRCAness' in sporadic cancers. Nat Rev Cancer. 2004;4(10):814-819.

124. Lin $\mathrm{PH}$, Chen M, Tsai LW, et al. Using next-generation sequencing to redefine BRCAness in triple-negative breast cancer. Cancer Sci. 2020;111(4):1375-1384. 
125. Mulligan JM, Hill LA, Deharo S, et al. Identification and validation of an anthracycline/cyclophosphamide-based chemotherapy response assay in breast cancer. $J$ Natl Cancer Inst. 2014;106(1):djt335.

126. Parkes EE, Walker SM, Taggart LE, et al. Activation of STING-Dependent Innate Immune Signaling By S-Phase-Specific DNA Damage in Breast Cancer. J Natl Cancer Inst. 2016;109(1):djw199. https://pubmed.ncbi.nlm.nih.gov/27707838/. Accessed November 08, 2020.

127. Heijink AM, Talens F, Jae LT, et al. BRCA2 deficiency instigates cGAS-mediated inflammatory signaling and confers sensitivity to tumor necrosis factor-alpha-mediated cytotoxicity. Nat Commun. 2019;10(1):100.

128. Reisländer T, Lombardi EP, Groelly FJ, et al. BRCA2 abrogation triggers innate immune responses potentiated by treatment with PARP inhibitors. Nat Commun. 2019;10(1):3143.

129. Pantelidou C, Sonzogni O, De Oliveria Taveira M, et al. PARP Inhibitor Efficacy Depends on CD8+ T-cell Recruitment via Intratumoral STING Pathway Activation in BRCA-Deficient Models of Triple-Negative Breast Cancer. Cancer Discov. 2019;9(6):722737.

130. Domchek SM, Postel-Vinay S, Im SA, et al. Olaparib and durvalumab in patients with germline BRCA-mutated metastatic breast cancer (MEDIOLA): an open-label, multicentre, phase 1/2, basket study. Lancet Oncol. 2020;21(9):1155-1164.

131. Pusztai L, Hyo SH, Yau C, et al. Evaluation of durvalumab in combination with olaparib and paclitaxel in high-risk HER2 negative stage II/III breast cancer: Results from the I-SPY 2 TRIAL [Abstract CT011]. Cancer Res. 2020;80(16_suppl):CT011. 
https://cancerres.aacrjournals.org/content/80/16_Supplement/CT011. Accessed: 09 November, 2020.

132. Thompson AM, Jordan LB, Quinlan P, et al. Prospective comparison of switches in biomarker status between primary and recurrent breast cancer: the Breast Recurrence In Tissues Study (BRITS). Breast Cancer Res. 2010;12(6):R92. Accessed: 12 November, 2020.

133. Angus L, Smid M, Wilting SM, et al. The genomic landscape of metastatic breast cancer highlights changes in mutation and signature frequencies. Nat Genet. 2019;51(10):1450-1458.

134. Gornstein EL, Sandefur S, Chung JH, et al. BRCA2 Reversion Mutation Associated With Acquired Resistance to Olaparib in Estrogen Receptor-positive Breast Cancer Detected by Genomic Profiling of Tissue and Liquid Biopsy. Clin Breast Cancer. 2018;18(2):184188.

135. Ashworth A. Drug resistance caused by reversion mutation. Cancer Res. 2008;68(24):10021-10023.

136. Sakai W, Swisher EM, Karlan BY, et al. Secondary mutations as a mechanism of cisplatin resistance in BRCA2-mutated cancers. Nature. 2008;451(7182):1116-1120.

137. Bouwman P, Aly A, Escandell JM, et al. 53BP1 loss rescues BRCA1 deficiency and is associated with triple-negative and BRCA-mutated breast cancers. Nat Struct Mol Biol. 2010;17(6):688-695. https://www.ncbi.nlm.nih.gov/pmc/articles/PMC2912507/. Accessed: 12 November, 2020.

138. Jaspers JE, Kersbergen A, Boon U, et al. Loss of 53BP1 causes PARP inhibitor resistance in Brca1-mutated mouse mammary tumors. Cancer Discov. 2013;3(1):68-81. https://www.ncbi.nlm.nih.gov/pmc/articles/PMC7518105/. Accessed: 12 November, 2020. 
139. Xu G, Chapman JR, Brandsma I, et al. REV7 counteracts DNA double-strand break resection and affects PARP inhibition. Nature. 2015;521(7553):541-544.

https://www.ncbi.nlm.nih.gov/pmc/articles/PMC4671316/. Accessed: 12 November, 2020.

140. Noordermeer SM, Adam S, Setiaputra D, et al. The shieldin complex mediates 53BP1dependent DNA repair. Nature. 2018;560(7716):117-121.

141. Mirman Z, Lottersberger F, Takai H, et al. 53BP1-RIF1-shieldin counteracts DSB resection through CST- and Pol $\alpha$-dependent fill-in. Nature. 2018;560(7716):112-116.

142. Ghezraoui H, Oliveira C, Becker JR, et al. 53BP1 cooperation with the REV7-shieldin complex underpins DNA structure-specific NHEJ. Nature. 2018;560(7716):122-127.

143. Dev H, Chiang TW, Lescale C, et al. Shieldin complex promotes DNA end-joining and counters homologous recombination in BRCA1-null cells. Nat Cell Biol. 2018;20(8):954965. 
Table 1: Mutated homologous recombination genes causing syndromes associated with hereditary breast cancer, and their estimated relative risks.

\begin{tabular}{|c|c|c|c|c|}
\hline Gene & Function & Syndrome & $\mathbf{R R}$ & Reference \\
\hline \multicolumn{5}{|c|}{ High-penetrance mutations } \\
\hline BRCA1 & $\begin{array}{l}\text { Encodes a tumour } \\
\text { suppressor, roles in } \\
\text { maintaining genomic } \\
\text { integrity. }\end{array}$ & $\begin{array}{l}\text { Hereditary } \\
\text { breast/ovarian } \\
\text { cancer syndrome }\end{array}$ & $>5$ & {$[31]$} \\
\hline$B R C A 2$ & $\begin{array}{lr}\text { Maintenance } & \text { of } \\
\text { genomic } & \text { integrity, } \\
\text { specifically the HR } \\
\text { pathway. }\end{array}$ & $\begin{array}{l}\text { Hereditary } \\
\text { breast/ovarian } \\
\text { cancer syndrome }\end{array}$ & $>5$ & {$[31]$} \\
\hline $\begin{array}{l}\text { Tumour protein } \\
\text { p53 (TP53) }\end{array}$ & $\begin{array}{l}\text { Encodes a tumour } \\
\text { suppressor, controls cell } \\
\text { cycle and activating } \\
\text { DNA repair proteins. }\end{array}$ & $\begin{array}{l}\text { Li-Fraumeni } \\
\text { Syndrome }\end{array}$ & $2-10$ & {$[36],[37]$} \\
\hline $\begin{array}{l}\text { Phosphatase and } \\
\text { tensin } \\
\text { homologue } \\
(P T E N)\end{array}$ & $\begin{array}{l}\text { Encodes a tumour } \\
\text { suppressor phosphatase } \\
\text { enzyme implicated in } \\
\text { cell proliferation, } \\
\text { survival and growth. }\end{array}$ & Cowden Syndrome & $2-10$ & {$[38],[39]$} \\
\hline $\begin{array}{l}\text { BRCA1-partner } \\
\text { and localiser of } \\
\text { BRCA2 } \\
(P A L B 2)\end{array}$ & $\begin{array}{l}\text { Encodes a protein that } \\
\text { interacts with BRCA2 } \\
\text { and required for some } \\
\text { functions of BRCA2 in } \\
\text { HR. }\end{array}$ & PALB2-related & $2-4 />5$ & {$[40],[41],[42]$} \\
\hline \multicolumn{5}{|c|}{ Moderate-penetrance mutations } \\
\hline $\begin{array}{l}\text { Checkpoint } \\
\text { kinase } 2 \\
(\text { CHEK2) }\end{array}$ & $\begin{array}{l}\text { Encodes a cell cycle } \\
\text { checkpoint kinase and is } \\
\text { an upstream regulator of } \\
\text { BRCA1. }\end{array}$ & CHEK2-related & $2-3$ & {$[43],[44]$} \\
\hline
\end{tabular}




\begin{tabular}{|l|l|l|l|l|}
\hline $\begin{array}{l}\text { Ataxia } \\
\text { telangiectasia } \\
\text { mutated }(A T M)\end{array}$ & $\begin{array}{l}\text { Encodes a cell cycle } \\
\text { checkpoint kinase and } \\
\text { coordinates DNA } \\
\text { repair. }\end{array}$ & [45],[46] \\
\hline $\begin{array}{l}\text { BRCA1 } \\
\text { interacting } \\
\text { protein C- } \\
\text { terminal } \\
\text { helicase 1 } \\
(B R I P 1)\end{array}$ & $\begin{array}{l}\text { Encodes a nuclear } \\
\text { protein that directly } \\
\text { interacts with BRCA1, } \\
\text { and is important to the } \\
\text { function of BRCA1 in } \\
\text { DSB repair. }\end{array}$ & & $2-3$ & {$[47],[48]$} \\
& & & & \\
\hline
\end{tabular}

RR, Relative risk; N/A, non-applicable. Table adapted from Mavaddat and colleagues ${ }^{49}$. 
Table 2: Clinically relevant breast cancer subtypes and the reported association with HR gene mutations.

\begin{tabular}{|c|c|c|c|}
\hline $\begin{array}{l}\text { Breast cancer } \\
\text { subtype }\end{array}$ & Receptor Expression & Description & $\begin{array}{l}\text { Associated } \\
\text { mutations }\end{array}$ \\
\hline Luminal A & ER+/HER2- & $\begin{array}{l}\text { - } \text { Includes a number of low-grade } \\
\text { variants } \\
\text { - } \quad \text { Typically grow slowly } \\
\text { - } \\
\text { Best prognosis } \\
\end{array}$ & $\begin{array}{l}\text { BRCA2 } \\
\text { PALB2 } \\
\text { ATM } \\
\text { CHEK2 }\end{array}$ \\
\hline Luminal B & $\begin{array}{l}\text { ER+/HER2+ } \\
\text { Or ER+/HER2-/Ki67 } \\
\text { high }\end{array}$ & $\begin{array}{l}\text { - Generally grow faster } \\
\text { - Worse prognosis than Luminal A } \\
\text { - Variable responses to therapies } \\
\text { such as endocrine and chemo }\end{array}$ & $\begin{array}{l}\text { BRCA2 } \\
\text { PALB2 } \\
\text { ATM } \\
\text { CHEK2 } \\
\text { TP53 }\end{array}$ \\
\hline HER2-enriched & ER-/HER2+ & $\begin{array}{ll}\text { - } & \text { High grade } \\
\text { - } & \text { Grow faster than Luminal cancers } \\
\text { - } & \text { Successfully treated with targeted } \\
& \text { therapies (e.g. trastuzumab) }{ }^{67-69}\end{array}$ & $\begin{array}{l}\text { BRCA2 } \\
\text { PALB2 } \\
\text { ATM } \\
\text { CHEK2 } \\
\text { RAD51C } \\
\text { RAD51D } \\
\text { TP53 }\end{array}$ \\
\hline $\begin{array}{l}\text { Basal-like } \\
\text { (TNBC) }\end{array}$ & ER-/PR-/HER2- & $\begin{array}{l}\text { - Do not respond to endocrine } \\
\text { therapy or trastuzumab } \\
\text { - Poor prognosis }\end{array}$ & $\begin{array}{l}\text { BRCA1 } \\
\text { RAD51D }\end{array}$ \\
\hline
\end{tabular}

$\mathrm{ER}=$ Estrogen receptor; PR $=$ Progesterone receptor; HER2 $=$ Human epidermal growth factor receptor 2 receptor; $\mathrm{TNBC}=$ Triple negative breast cancer; + , positive for receptor expression; -, negative for receptor expression; Ki67, protein encoded by the MKI67 gene, higher Ki67 is associated with higher grade and aggressive cancers. 


\section{Accepted Article}

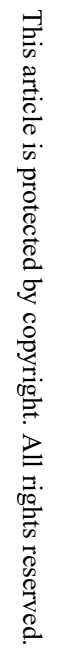

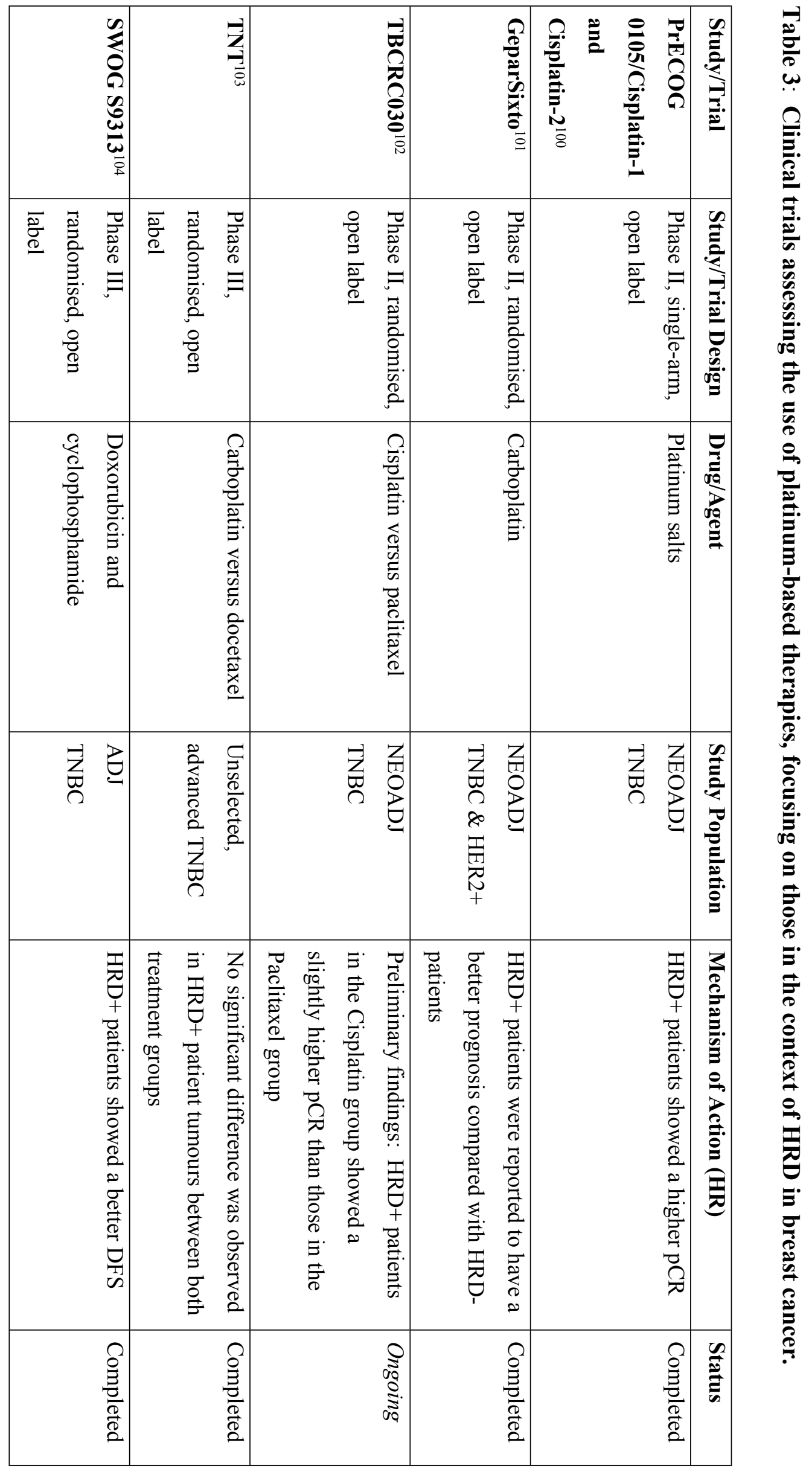


Accepted Article

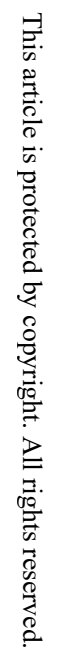

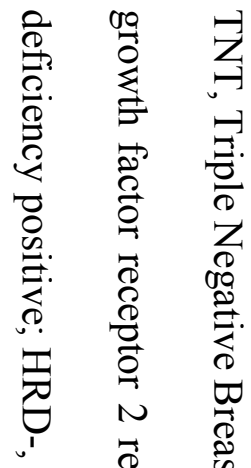

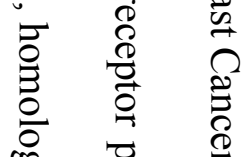

染

$\overrightarrow{0}$ 룽

它. 氝

营 节

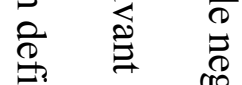

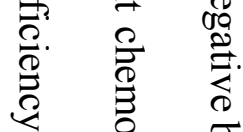

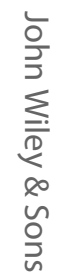

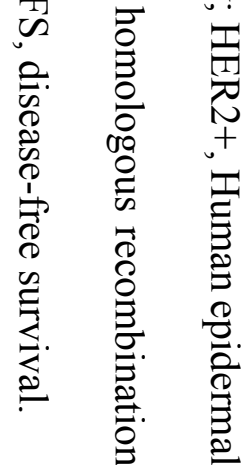


Accepted Article

$\frac{d}{2}$

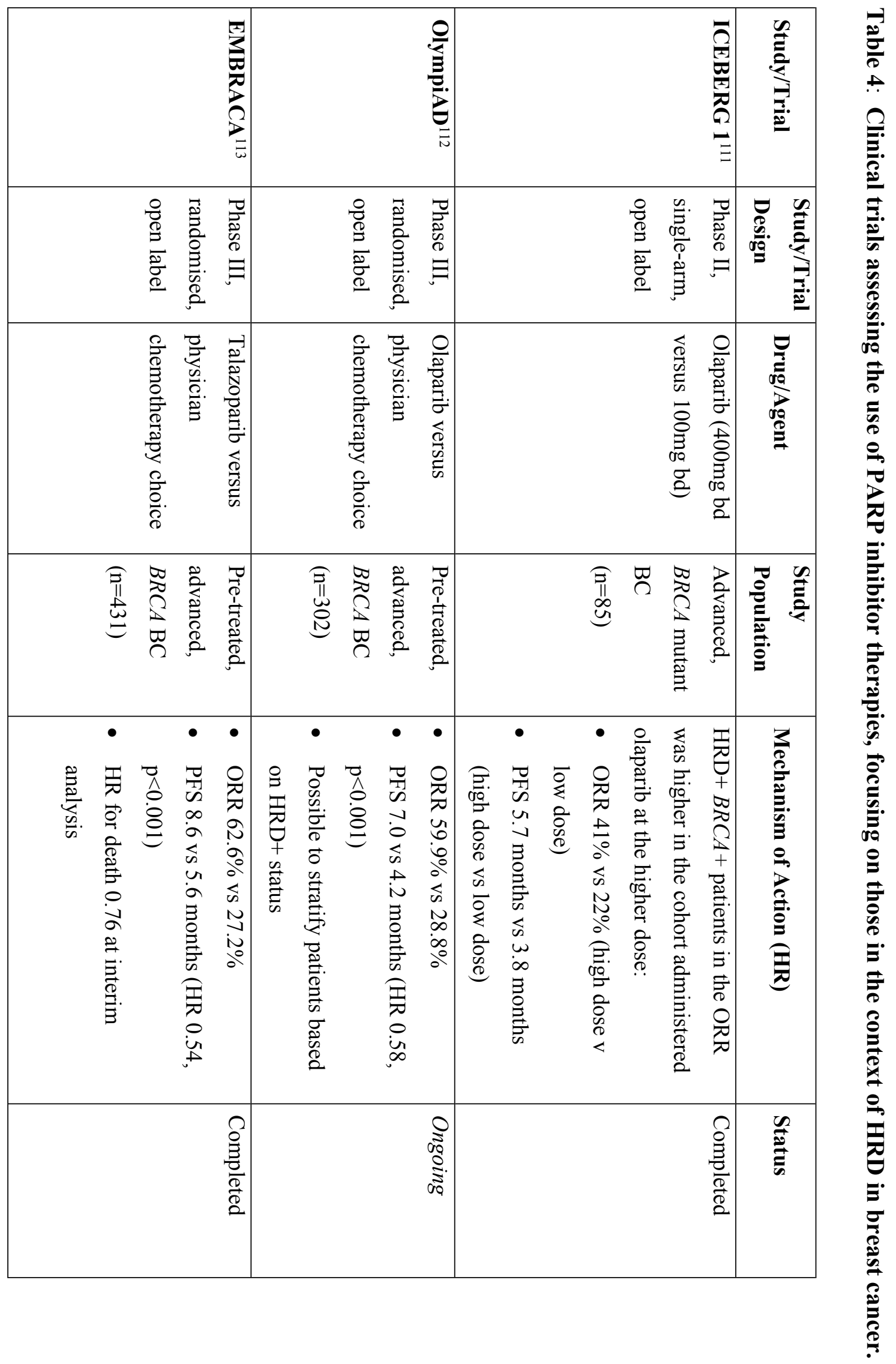


Accepted Article

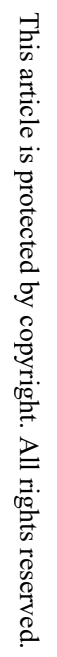

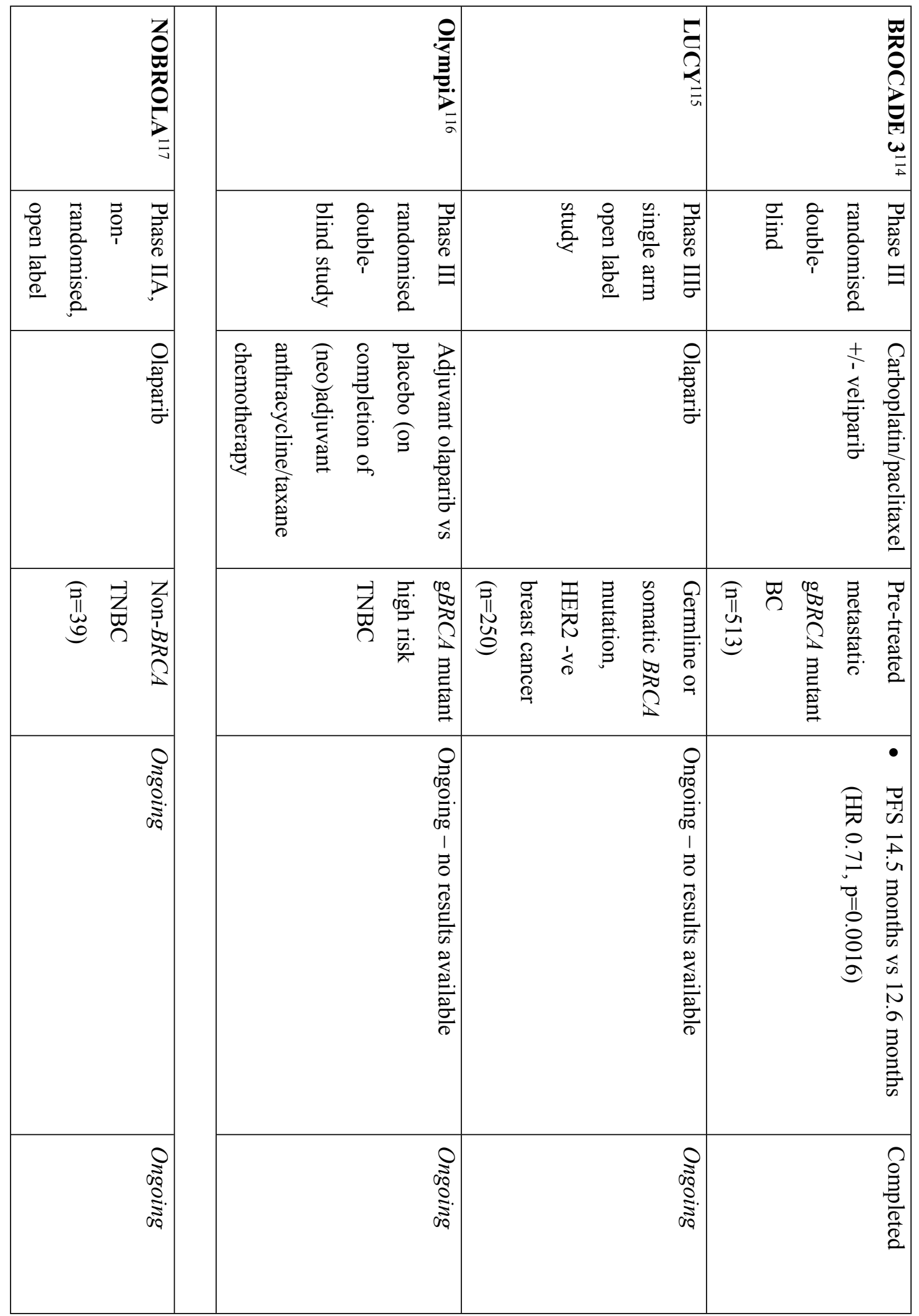




\section{Accepted Article}

I

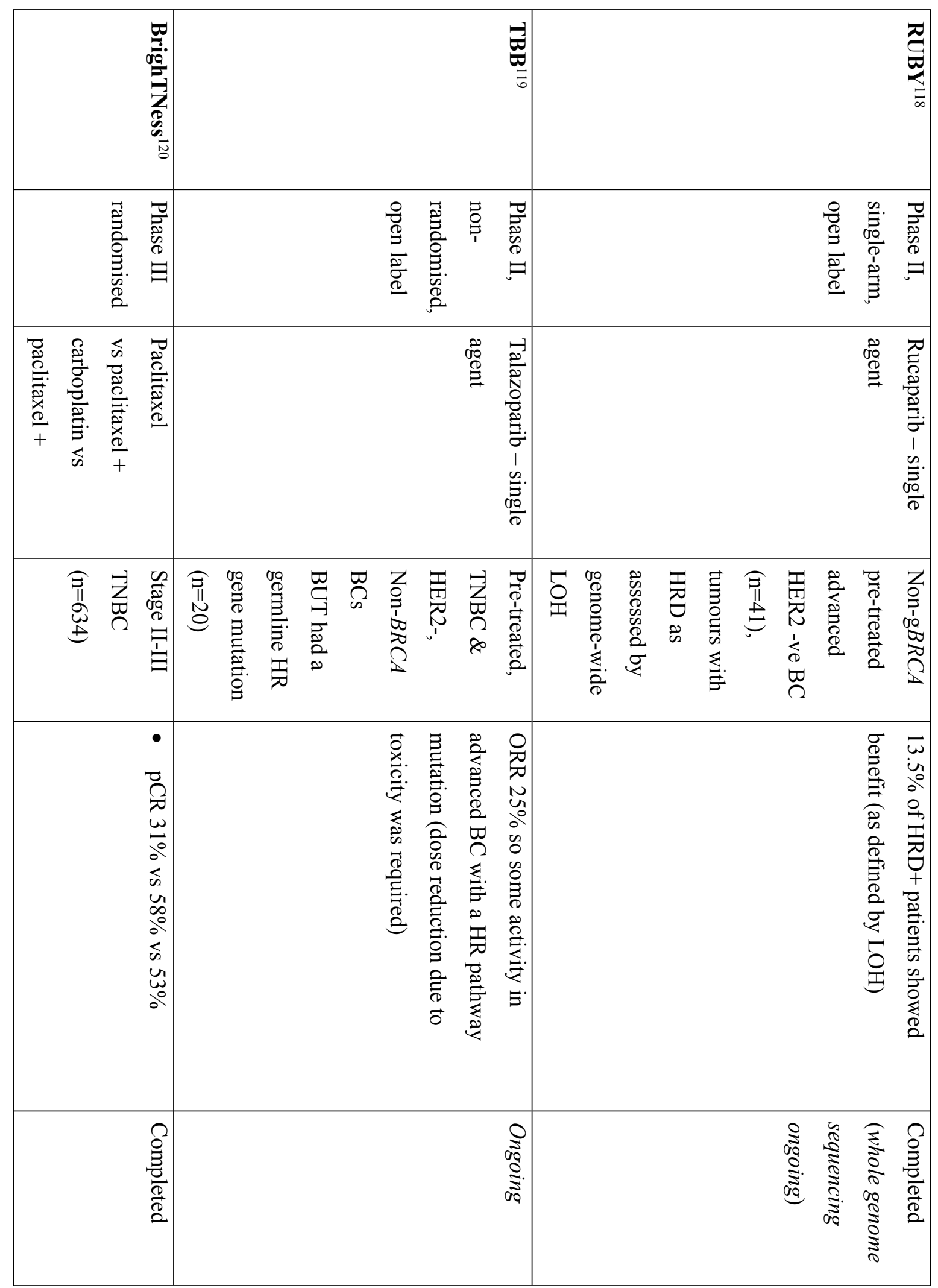


Accepted Article

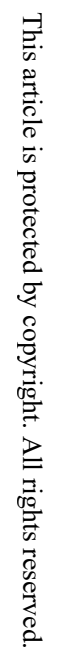

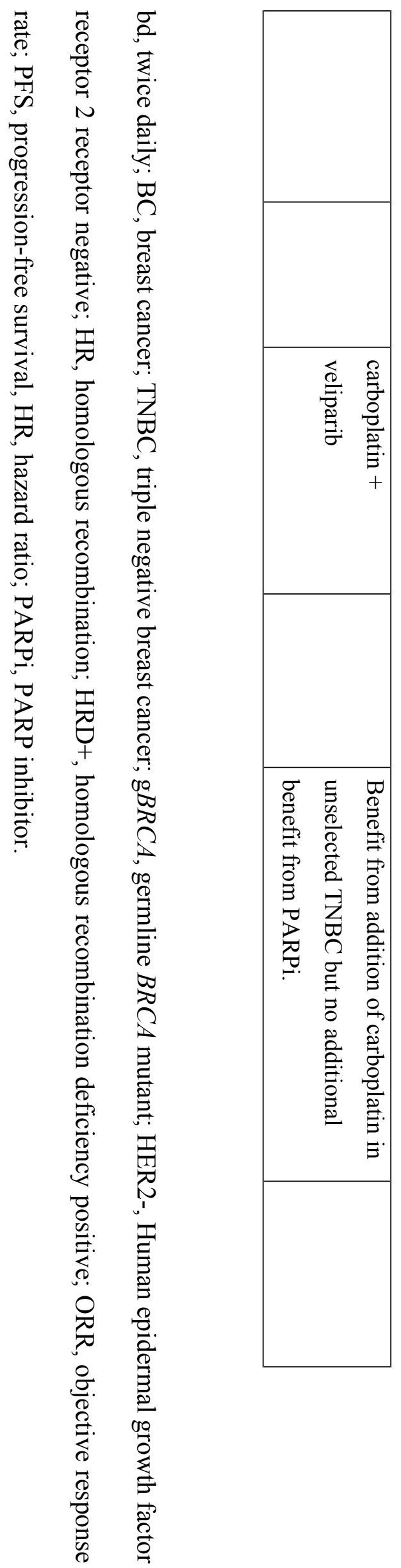




\section{Figure 1: The homologous recombination (HR) DNA repair pathway}

The main HR proteins and mechanisms are illustrated. The MRN complex initially senses breaks in the DNA, in combination with the human single strand binding protein (hSSB1). The MRN complex is composed of meiotic recombination 11 (MRE11), the DNA repair protein RAD50 and Nijmegen breakage syndrome 1 (NBS1). MRN binds to the breakage site which both recruits and activates the checkpoint protein kinases ATM and CHK2, which in turn phosphorylate a number of substrates. BRCA1 associates with $\mathrm{C}$-terminal binding protein interacting protein (CtIP), which then further interacts with the MRN complex. Then, DNA end resection begins by the nuclease MRE11, leaving 3' single-stranded DNA (ssDNA) overhangs at the DSB sites. These overhangs are coated with replication protein A (RPA) to form a nucleoprotein filament. RPA is displaced by partner and localiser of BRCA2 (PALB2) that recruits BRCA2, which loads the recombinase RAD51. This generates the Rad51-ssDNAnucleoprotein filament that invades the homologous site on the double-stranded homologous sister chromatid leading to the error-free repair of DNA. 


\section{Figure 2: HR Deficiency (HRD) aetiology}

The three types of HRD aetiology include epigenetic modifications (promoter methylation), structural rearrangements (LOH, TAI and LST - part of the 'genomic scar') and mutations (germline $B R C A$, germline HR genes and somatic HR mutations). These can lead to the inability of the HR pathway to repair damaged DNA and thus genomic instability as the damaged DNA is not efficiently resolved. Consequently, this can lead to the development of cancer, such as breast cancer development. g, germline; HR, homologous recombination; HRD homologous recombination deficiency; LOH, loss of heterozygosity; TAI, telomeric allelic imbalance; LST, large-scale state transitions. 


\section{Figure 3: Synthetic lethality in the context of HR and PARP inhibitor}

The top boxed panel illustrates the normal circumstance whereby SSBs are repaired in the presence of PARP, during which the cell survives. When PARP is inhibited using a PARPi, SSBs are not repaired and in the case of some PARPis, PARP is trapped at the SSBs - both lead to replication fork stalling due to replication fork collision with the SSBs and/or trapped PARP. In HR proficient cells, the stalled replication forks are rescued by the HR proteins, which rescue the stalled fork via the HR pathway; as indicted in the left-arm of the diagram. Consequently, the cell survives. Contrary to this, as indicted in the right-arm of the diagram, in cells with an HRD, the stalled replication forks are not rescued leading to replication fork collapse and the accumulation of S-phase DSBs. These are not repaired in the context of an HRD, ultimately leading to cell death. In this case, the lack of HR to repair excessive damage caused by loss of PARP demonstrates synthetic lethality. SSBs, single-stranded breaks; HR, homologous recombination; HRD-, HR deficiency negative; HRD+, HR deficiency positive; PARPi, PARP inhibitor; DSBs, double-stranded breaks. 

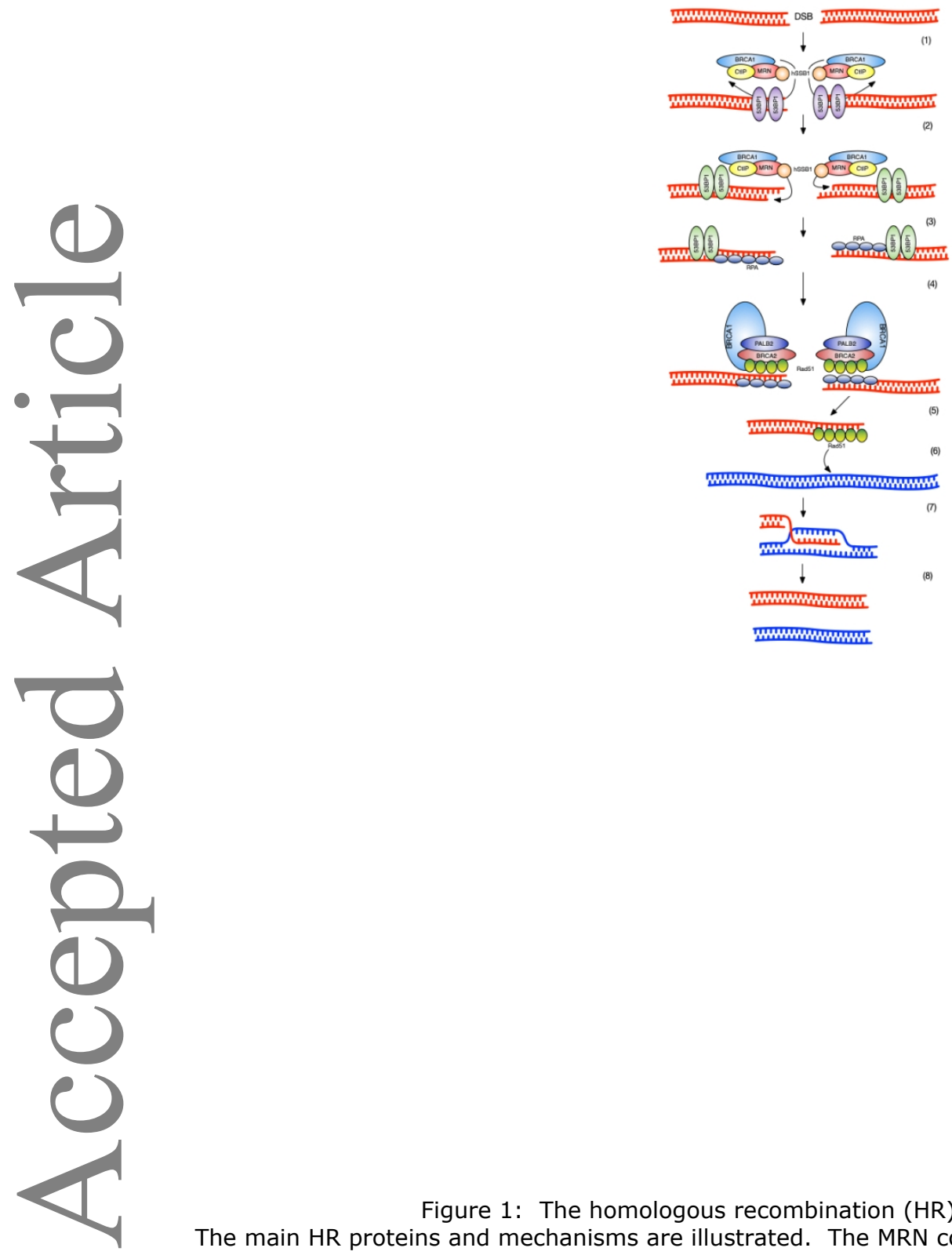

Figure 1: The homologous recombination (HR) DNA repair pathway.

The main HR proteins and mechanisms are illustrated. The MRN complex initially senses breaks in the DNA, in combination with the human single strand binding protein (hSSB1). The MRN complex is composed of meiotic recombination 11 (MRE11), the DNA repair protein RAD50 and Nijmegen breakage syndrome 1 (NBS1). MRN binds to the breakage site which both recruits and activates the checkpoint protein kinases ATM and CHK2, which in turn phosphorylate a number of substrates. BRCA1 associates with C-terminal binding protein interacting protein (CtIP), which then further interacts with the MRN complex. Then, DNA end resection begins by the nuclease MRE11, leaving 3' single-stranded DNA (sSDNA) overhangs at the DSB sites. These overhangs are coated with replication protein A (RPA) to form a nucleoprotein filament. RPA is displaced by partner and localiser of BRCA2 (PALB2) that recruits BRCA2, which loads the recombinase RAD51. This generates the Rad51-sSDNA-nucleoprotein filament that invades the homologous site on the double-stranded homologous sister chromatid leading to the error-free repair of DNA. 

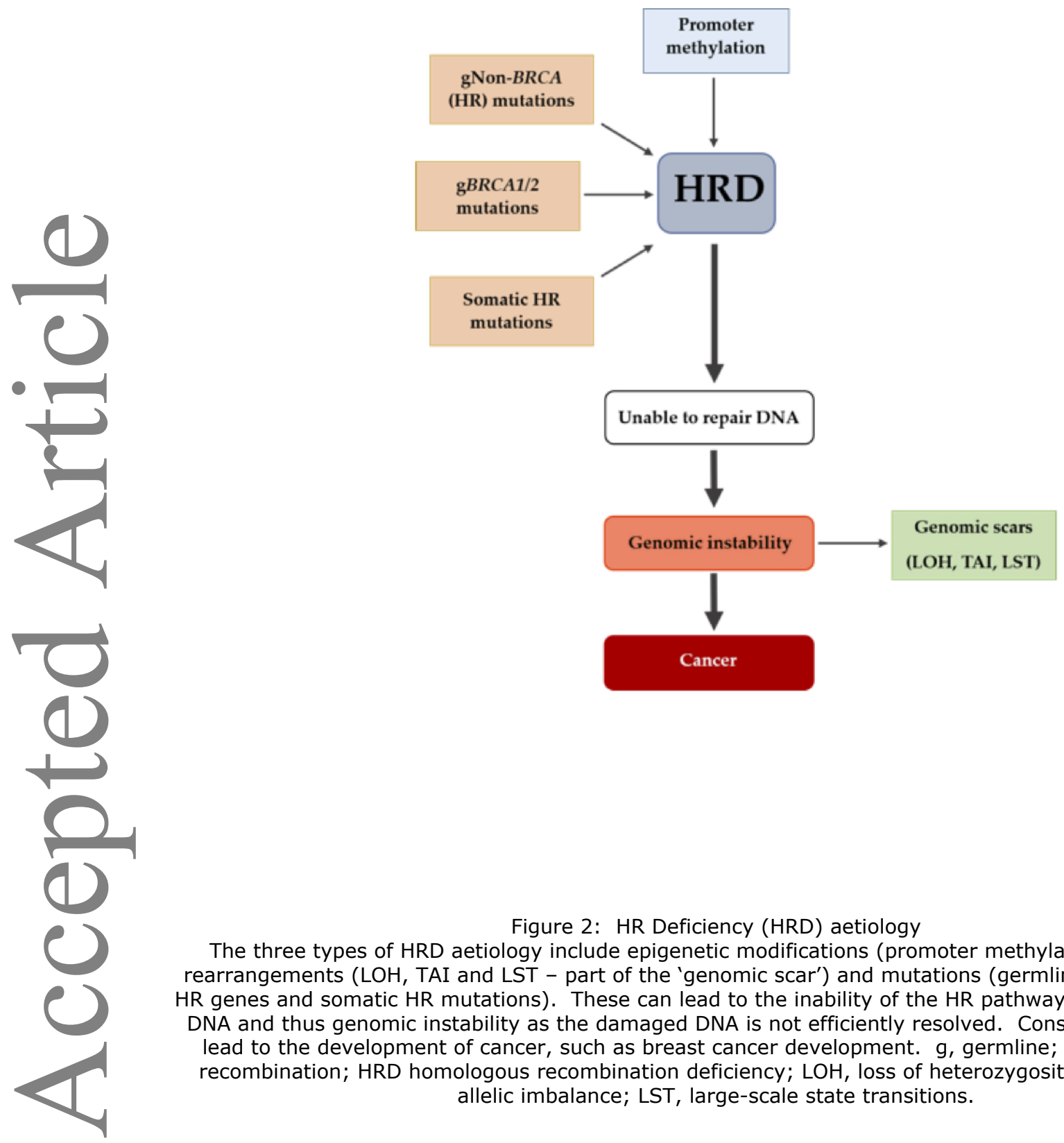

Figure 2: HR Deficiency (HRD) aetiology

The three types of HRD aetiology include epigenetic modifications (promoter methylation), structural rearrangements (LOH, TAI and LST - part of the 'genomic scar') and mutations (germline BRCA, germline HR genes and somatic HR mutations). These can lead to the inability of the HR pathway to repair damaged DNA and thus genomic instability as the damaged DNA is not efficiently resolved. Consequently, this can lead to the development of cancer, such as breast cancer development. g, germline; HR, homologous recombination; HRD homologous recombination deficiency; $\mathrm{LOH}$, loss of heterozygosity; TAI, telomeric allelic imbalance; LST, large-scale state transitions.

$159 \times 158 \mathrm{~mm}(150 \times 150 \mathrm{DPI})$ 

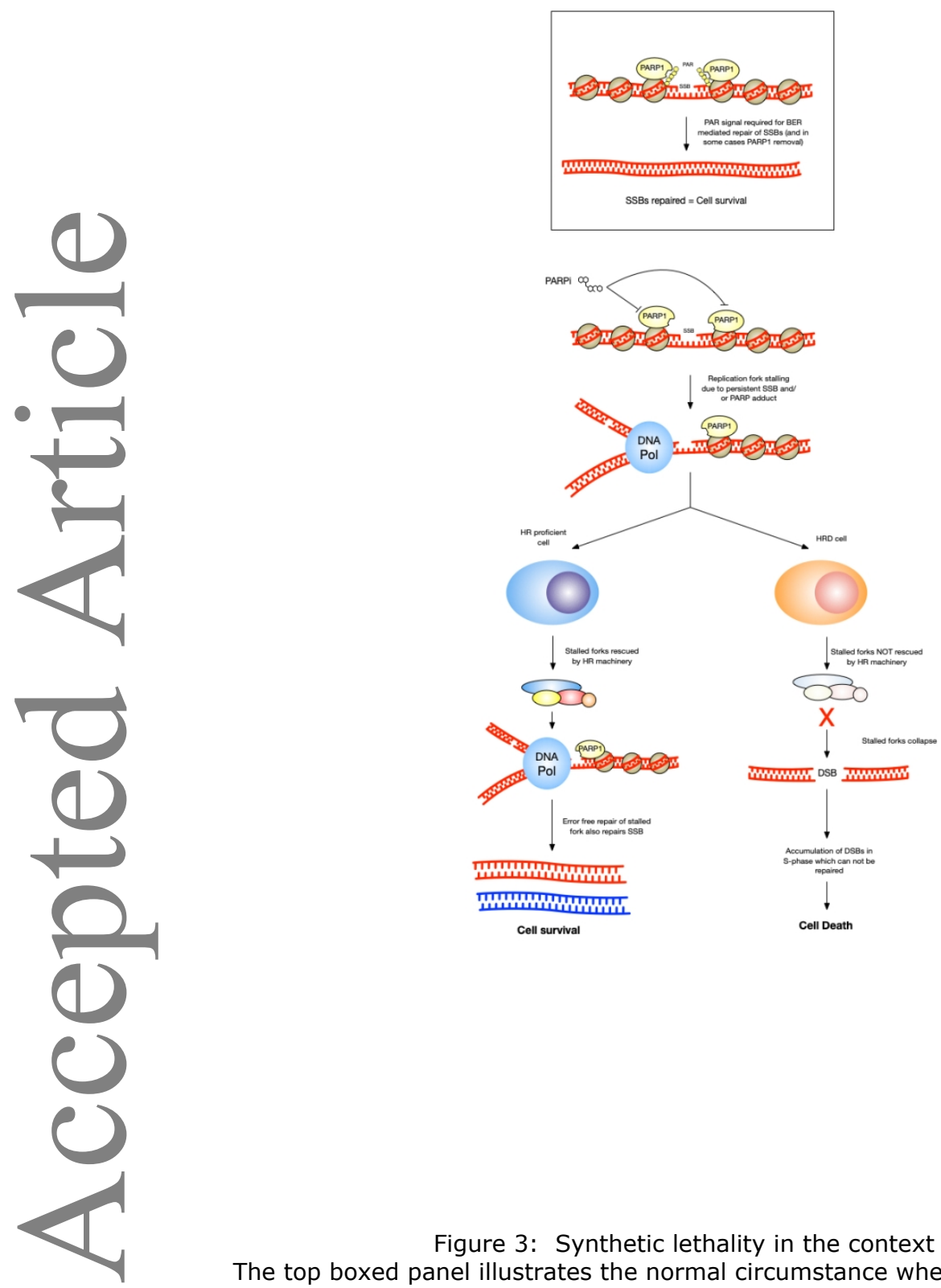

Figure 3: Synthetic lethality in the context of HR and PARP inhibitor

The top boxed panel illustrates the normal circumstance whereby SSBs are repaired in the presence of PARP, during which the cell survives. When PARP is inhibited using a PARPi, SSBs are not repaired and in the case of some PARPis, PARP is trapped at the SSBS - both lead to replication fork stalling due to replication fork collision with the SSBs and/or trapped PARP. In HR proficient cells, the stalled replication forks are rescued by the HR proteins, which rescue the stalled fork via the HR pathway; as indicted in the left-arm of the diagram. Consequently, the cell survives. Contrary to this, as indicted in the right-arm of the diagram, in cells with an HRD, the stalled replication forks are not rescued leading to replication fork collapse and the accumulation of S-phase DSBs. These are not repaired in the context of an HRD, ultimately leading to cell death. In this case, the lack of HR to repair excessive damage caused by loss of PARP demonstrates synthetic lethality. SSBs, single-stranded breaks; HR, homologous recombination; HRD-, HR deficiency negative; HRD+, HR deficiency positive; PARPi, PARP inhibitor; DSBs, double-stranded breaks. 